\title{
De crisis in de rechtse samenwerking (1925-1926)
}

\author{
L. C. SUTTORP
}

\section{INLEIDING (1918-1925)}

Bij de verkiezingen voor de Tweede Kamer, kort voor het eindigen van de Eerste Wereldoorlog, viel de uitslag moeilijk te voorspellen. Men beschouwde het als een verdienste van het oorlogskabinet-Cort van der Linden (1913-1918), dat de neutraliteit van Nederland tot dusver gehandhaafd was gebleven en dat het ons land veilig door vaak moeilijke situaties had weten te loodsen. Maar het lag voor de hand dat, als de oorlog eenmaal zou zijn afgelopen, het herstel van de normale toestand beter aan een nieuw team kon worden overgedragen. Van de uitslag der verkiezingen verwachtte men een duidelijk antwoord op de vraag, aan welke partijen die opdracht zou te beurt vallen. Inzake eventuele samenwerking waren er vóór de verkiezingen door de partijen geen afspraken gemaakt. Elke partij was er op uit zo veel mogelijk stemmen in den lande te verwerven.

Van de honderd gekozenen behoorden er 52 tot de rechterzijde. Hiervan behaalden de drie zogenaamde confessionele partijen 50 zetels, aldus verdeeld: de roomskatholieken 30, de anti-revolutionairen 13, de christelijk-historischen 7 zetels. De krappe rechtse meerderheid (52 zetels) was te danken aan twee eenmansfracties.

De linkerzijde vertoonde een opvallende verdeeldheid. De 48 zetels werden geleverd door niet minder dan 12 partijen en partijtjes (waaronder zes eenmansfracties !). De Sociaal-Democratische Arbeiderspartij (SDAP) vormde met haar 22 zetels de grootste aaneengesloten groep. Verder beschikten de verdeelde liberaalgezinden over 13, de Vrijzinnig-Democraten over 5 zetels. Daarnaast speelden de minuscule fracties een te verwaarlozen rol. De linkerzijde miste blijkbaar eenheid van visie. Die bezaten de rechtse partijen wel, omdat ze volgens de bekende uitdrukking 'stoelden op één wortel des geloofs'. Al dachten ze over allerlei kwesties niet gelijk, hun op christelijke beginselen gebaseerde levensbeschouwing vormde een bruikbare grondslag voor een samenwerking in coalitieverband, zoals bij vroegere kabinetten gebleken was.

De vraag rees of het rechtse zeteltal wel een soliede fundament vormde voor de zware taak die wachtte. Aanvankelijk werd er dan ook gedacht aan de niogelijk- 
heid van een gemengd kabinet om aldus een steviger parlementaire grondslag te kunnen vormen. In de gegeven situatie bleek dit echter niet te realiseren. Met name dr. Nolens, leider van de rooms-katholieke Kamerfractie, hield vast aan zijn ideaal: een zuiver rechts ministerie, onder leiding van een rooms-katholieke premier. Dat lag ook wel in de lijn, want rechts had nu eenmaal de meerderheid en zijn partij telde meer zetels dan de beide protestantse partijen tezamen. Maar een rooms-katholieke formateur en een rooms-katholieke premier waren tot nu toe ongehoord en vooral in christelijk-historische kringen, van nature meer bevreesd voor 'roomse overheersing' dan de anti-revolutionairen, voelde men daar weinig voor. In de gegeven omstandigheden zag men echter geen andere oplossing.

En zo kwam, dank zij het doorzettingsvermogen van Nolens, die als formateur het terrein grondig had verkend, een coalitiekabinet tot stand, met de rooms-katholieke jhr. Ruys de Beerenbrouck als premier, vier rooms-katholieke, drie antirevolutionaire en een christelijk-historische minister. Van de overige bewindslieden (onder andere de minister van Buitenlandse Zaken jhr. van Karnebeek) was de politieke kleur wat minder duidelijk.

Het kabinet-Ruys stond in de na-oorlogse jaren voor een moeilijke opdracht. En men had niet voorzien dat deze nog verzwaard werd door complicaties in de buitenlandse politiek (onder andere de uitlevering van de Duitse keizer en strubbelingen met ons buurland België). Maar deze problemen waren van voorbijgaande aard. De taken die bleven ten aanzien van de binnenlandse politiek bleven nog zwaar genoeg. Al denkt men alleen maar aan het afwikkelen van de oorlogssituatie: opheffing van het distributiesysteem van levensmiddelen, demobilisatie; en aan het economisch herstel: aanvulling van de nodige grondstoffen en verhoging van de productie. De naweeën van de oorlog bleken erger dan men zich had kunnen voorstellen. Men stond voor de noodzaak van het aflossen van schulden, de bestrijding van de werkloosheid, het op gang brengen van in- en uitvoer. Verder bleek dat de ontwrichting in het buitenland en de koopkrachtvermindering (Duitsland!) aan ons land niet voorbijging.

De oorlogsjaren hadden een normale gang van zaken in allerlei opzichten onmogelijk gemaakt of afgeremd. Het werd hoog tijd om ook hervormingen in te voeren die 'pasten bij de polsslag van deze nieuwe tijd'. Men was achterop geraakt op het schema van sociale voorzieningen en de sociale wetgeving eiste dringend verdere uitbreiding. Voorts moest er noodzakelijk een wet op het onderwijs worden tot stand gebracht nu bij de grondwetsherziening van 1917 de financiële gelijkstelling tussen bijzonder en openbaar onderwijs in principe was vastgelegd.

Zo kwamen er op korte termijn enkele belangrijke sociale wetten tot stand (onder andere een ouderdomsvoorziening en een achturige werkdag). En de christelijkhistorische minister van onderwijs dr. J. Th. de Visser wist reeds in 1920 een onderwijswet in het Staatsblad te brengen, die zowel rechts als links bevredigde. 


\section{C. SUTTORP}

De keerzijde van de medaille was echter, dat de uitvoering van genoemde wetten exorbitante uitgaven nodig maakte. De financiën gingen ernstige zorg baren. Het ongeluk wilde, dat dit gebeurde in de jaren dat er veel geld moest worden uitgetrokken voor noodzakelijk geachte militaire voorzieningen. Meer dan één minister van oorlog en van marine moest 'op het veld van eer' het einde van zijn kortstondige gouvernementele carrière beleven. Zelfs een kabinetscrisis is ermee gemoeid geweest (in 1921), die evenwel het bestaande ministerie behoudens enkele persoonswisselingen deed terugkeren.

De Kamerverkiezing (mede in verband met de in dat jaar klaar gekomen grondwetsherziening) in 1922 werd een duidelijke overwinning van de rechtse coalitiepartijen. De verhouding werd: rechts 60, links 40 zetels. Men kon dit uitleggen als een goedkeuring van het tot nu toe gevoerde beleid. Maar de tegenstanders van de coalitie legden het accent op een andere verklaring: de verschuiving was te beschouwen als een gevolg van het voor het eerst toepassen van het vrouwenkiesrecht, waardoor de behoudende vleugel van het kiezerscorps een flinke steun in de rug gekregen had.

Inderdaad leek er weinig reden tot juichen over de nieuwe samenstelling van de Kamer. Dat bleek onder andere uit het feit dat men, ondanks de sprekende winst en de duidelijke meerderheid, niet een-twee-drie een rechts kabinet kon formeren. Nadat de kabinetscrisis een paar maanden had geduurd kwam het ministerieRuys, gereconstrueerd met enkele departementale wijzigingen, weer aan het roer. Bij de lange duur van de crisis speelde ook mee, dat onder de protestanten de vrees voor roomse invloed en machtsbegeerte toenam. Dat bijvoorbeeld èn de premier èn de beide Kamervoorzitters rooms-katholiek waren vond men 'al te veel van het goede'. Het anti-papisme bleek nog levend.

Doch er waren urgenter kwesties aan de orde. Reeds lang was uitbreiding van onze vloot een zaak van zorg en bezorgdheid. Het was ook een aangelegenheid waarmee grote bedragen gemoeid zouden zijn. De man in the street kon zulk een miljoenenzaak onmogelijk rijmen met de benarde financiële toestand, zich manifesterend in lage lonen, salarisverlagingen en bezuinigingen op allerlei terrein. De groei van het lager onderwijs, waarvan men zich in 1920 zo veel had voorgesteld, moest worden afgeremd. De klok van de sociale wetgeving diende te worden teruggezet: de achturige werkdag bleek te hoog gegrepen en werd gewijzigd in een acht-en-eenhalf durende. En ondanks dit alles en nog veel meer zou de defensie miljoenen moeten gaan kosten, extra-miljoenen zelfs? Er was toch, zo redeneerde men, geen sprake van oorlog of oorlogsdreiging, zo kort na de gebluste wereldbrand? En waren we niet lid geworden van de Volkenbond, die internationale conflicten zou moeten voorkomen? Voor velen scheen het overdreven, dat de regering de defensie-uitgaven verdedigde met het argument, dat we in internationaal verband ook zelf moesten opkomen voor onze onafhankelijkheid en dat we met het oog daarop of- 
fers moesten brengen. Reeds werd de leus van 'nationale ontwapening' gehoord. Maar de regering hield voet bij stuk. Het feit dat Nederland een koloniale mogendheid was met een uitgestrekt en kwetsbaar gebied in de ver weg gelegen Stille Oceaan, waar de grote mogendheden vitale en tegenstrijdige belangen hadden, onderstreepte de noodzaak van een serieuze behartiging van ons eigen landsbelang. Vooral met het oog op de beveiliging van ons Indië moest aan de marine-uitbreiding hoge prioriteit worden verleend. Het scheen wenselijk de uitgaven over een aantal jaren te verdelen en wettelijk vast te leggen. Verschil van mening hierover leidde tot het aftreden van de toenmalige minister van Financiën (jhr. De Geer, $\mathrm{CH}$ ) en zijn vervanging door H. Colijn (AR) in de zomer van 1923.

Najaar 1923 zou de eigenlijke beslissing vallen. De langzaam berucht geworden 'vlootwet' werd in stemming gebracht en met 50 tegen 49 stemmen verworpen (één lid van de rechterzijde ontbrak). Afgezien van de financiële en militaire kant van de zaak is vooral één punt de vermelding waard: bij de 49 tegenstemmers behoorden tien katholieke afgevaardigden, die bij deze gelegenheid als 'democraten' een eigen geluid wensten te doen horen. Politiek gesproken was het een barst in de coalitie, want het kabinet had vooraf aangekondigd zich niet te zullen neerleggen bij een eventuele verwerping. Een kabinetscrisis was het gevolg, die weer maanden in beslag nam, ondanks of dank zij de meest uiteenlopende pogingen om tot een oplossing te komen. De oplossing zelfwas hoogst merkwaardig: het kabinet-Ruys keerde in dezelfde samenstelling terug, omdat de koningin tenslotte weigerde het gevraagde ontslag te aanvaarden.

Vervolgens legde het kabinet zich bij de verwerping der vlootwet noodgedwongen neer. Er viel genoeg ander werk te doen. Gelukkig kwam de financiële toestand in een wat gunstiger licht te staan. De forse bezuinigingspolitiek van de nieuwe minister van Financiën had blijkbaar succes.

Aldus ontwikkelde Colijn zich tot de centrale figuur in het kabinet. Enerzijds geprezen om zijn energieke financiële beleid, anderzijds bekritiseerd en zelfs fel bestreden vanwege zijn belastingpolitiek en zijn harde bezuinigingen, die volgens zijn beschuldigers vooral 'de kleine man' raakten. Het had er alle schijn van, dat bij de volgende verkiezingscampagne één van de meest aansprekende verkiezingsleuzen zou worden: vóór of tegen de politiek van Colijn.

\section{FORMATIE VAN HET KABINET COLIJN (1925)}

In de zomer van het jaar 1925 hadden de verkiezingen voor de Tweede Kamer plaats. Het was de vraag of de linkse partijen (socialisten, vrijzinnig-democraten, liberalen) erin zouden slagen aan het Nederlandse volk duidelijk te maken, dat de rol van de rechtse groeperingen ( $\mathrm{RK}, \mathrm{AR}, \mathrm{CH}$ ) in coalitieverband was uitgespeeld. De politieke partijen en de Nederlandse kiezers hadden nu al zeven jaren aangeke- 


\section{C. SUTTORP}

ken tegen een rechts kabinet, onder leiding van steeds dezelfde premier (jhr. Ruys de Beerenbrouck). Het was een periode van vallen en opstaan geweest, met veelvuldige ministerwisselingen en meer dan één lastige kabinetscrisis. Golden deze verschijnselen niet als het bewijs dat de coalitie op een vrij zwakke basis rustte? Men had de indruk, dat de regering zo lang stand gehouden had bij gebrek aan een bruikbaar alternatief. Tegen deze achtergrond scheen links ditmaal de grootste kansen te hebben.

Toch was de stembusuitslag niet bepaald schokkend te noemen. De tijd was blijkbaar nog niet rijp voor een radicale politieke verschuiving. De wijzigingen in de samenstelling van de Kamer van honderd waren dan ook minimaal. De rechterzijde liep terug, maar met slechts twee zetels (van 60 op 58). Daartegenover behield links een sterke minderheid (42 zetels).

Op grond van deze uitslag lag een nieuw rechts kabinet voor de hand. Het zou zelfs een coalitiekabinet van de drie grote partijen kunnen zijn, daar deze samen toch nog over 54 zetels beschikten. Maar dat er weer een kabinet-Ruys zou komen leek in de gegeven omstandigheden niet waarschijnlijk. Vriend en vijand waren langzamerhand op de weliswaar verdienstelijke, maar niet bepaald krachtige premier uitgekeken. Men was van oordeel, dat het kabinet in de lang niet gemakkelijke na-oorlogse jaren nu wel zijn Schuldigkeit gedaan had en dat het tijd werd, dat er weer een frisse wind ging waaien door het regeerkasteel.

Van protestantse zijde meende men, dat het ook gewenst was dat er weer een niet-katholiek als formateur en leider zou optreden, zoals het in de coalitiekabinetten vóór de oorlog traditie was geweest. Met het oog hierop werd al de naam genoemd van de anti-revolutionaire leider $\mathrm{H}$. Colijn. In de laatste jaren was hij als minister van Financiën nogal op de voorgrond getreden. In die kwaliteit had hij zich doen kennen als de minister van bezuiniging en de paladijn van de sluitende begroting. Wel stond daartegenover dat zijn politiek, vooral door de linkse groeperingen, fel bestreden was. Ook in sommige rechtse kringen bestonden er weerstanden tegenover de door hem toegepaste bezuinigingsmethodes. In die dagen was hij in 't algemeen gesproken geen persona grata, al hadden zijn geestverwanten hem de reputatie bezorgd van de 'redder van de gulden'. Maar het feit, dat de AR partij bij de verkiezing niet minder dan drie zetels verloor gaf aan de oppositie een sterke troef in handen.

Al met al was de politieke situatie nogal gecompliceerd. Dat kwam ook tot uitdrukking in de schriftelijke adviezen die met het oog op de aanstaande kabinetsformatie aan koningin Wilhelmina werden uitgebracht. Die adviezen geven namelijk uit de aard der zaak meer dan alleen de naam van de een of andere politicus die door een Kamerfractie voor de taak het meest geschikt of althans aanvaardbaar werd geacht. Wel zijn ze op deze naamsvermelding toegespitst, maar tegelijkertijd bieden ze enige achtergrondinformatie betreffende de politieke omstandig- 
heden van het ogenblik. Suggesties voor de opheffing van de impasse dienden immers met redenen omkleed te zijn, opdat het staatshoofd het vóór en tegen kon afwegen alvorens een beslissing te nemen.

Het was te voorzien dat er weer een rechts kabinet zou komen. De Kamermeerderheid wees in die richting en de rechtse partijen wilden de samenwerking zo enigszins mogelijk voortzetten. De centrale vragen daarbij waren: of er weer een coalitiekabinet zou optreden; zo ja, of het oude, zij het in gereconstrueerde vorm, zou blijven of dat er een geheel nieuw zou worden gevormd door een alsnog aan te wijzen formateur.

De AR fractie was, ondanks waardering voor hetgeen de regering-Ruys had gepresteerd, van oordeel dat na zeven jaren slechts een nieuw kabinet de weg zou kunnen openen voor een krachtig en vruchtbaar beleid in de toekomst ${ }^{1}$. Ook de $\mathrm{CH}$ fractie sprak zich uit voor een geheel nieuw kabinet ${ }^{2}$. Hoewel de verdiensten van het demissionaire bewind werden erkend, kon een terugkeer zelfs op een gereconstrueerde basis beter achterwege blijven, meende men.

Tussen de beide protestantse fracties bestond er wel enig verschil ten aanzien van een aan te wijzen formateur. De fractievoorzitter van de AR, mr. V. H. Rutgers, wees erop dat Colijn 'door de omstandigheden' daartoe aangewezen scheen. Het voornaamste motief was: Colijn had zijn stempel gedrukt op het financiële beleid, waarom het in de verkiezingsstrijd was gegaan en daarbij had hij 'moed, voortvarendheid, bekwaamheid en volharding' aan de dag gelegd. Deze aanbeveling zou echter slechts van kracht blijven, aldus de adviseur, indien door de andere rechtse partijen geen andere gegadigden zouden worden genoemd. Gezien de te verwachten linkse oppositie moest immers de regering kunnen rekenen op de krachtige steun van de rechterzijde. Als Colijn door de anderen niet werd gewild kon de opdracht beter niet aan hem worden verleend, want dan zou de 'duidelijke roeping' ontbreken.

Aan de gestelde voorwaarde werd in zoverre niet voldaan dat de $\mathrm{CH}$ fractie inderdaad een andere figuur naar voren schoof, namelijk die van jhr. mr. D. J. de Geer. Maar primair en met enige nadruk sprak de $\mathrm{CH}$ adviseur, mr. J. Schokking, de wenselijkheid uit dat er ditmaal een protestantse formateur zou worden aangewezen. Hierbij kan worden opgemerkt dat ook het AR advies daarop speciaal de

1. V. H. Rutgers aan H.M. de koningin, 9 juli 1925 (dossier De Visser). Genoemd dossier (toevalligerwijs via een bevriende relatie van de familie De Visser in mijn bezit gekomen) bestaat uit een bundeltje stukken uit de jaren twintig. Voor het merendeel bevatten ze: enkele door de kabinetsformateur dr. J. Th. de Visser in 1925-1926 aan de koningin uitgebrachte rapporten; een aantal aan het staatshoofd gerichte adviezen van fractieleiders; zakelijke brieven (originele en kopieën) die in genoemde jaren werden gewisseld tussen de bij de formatie betrokkenen, met name brieven van de formateur zelf, van de voorzitter van de raad van ministers, van kamerleden, van de directeur van het kabinet der koningin.

2. J. Schokking aan H.M. de koningin, 8 juli 1925, dossier De V. 


\section{C. SUTTORP}

aandacht vestigde. Kennelijk waren beide groeperingen beducht, dat het precedent van een rooms-katholieke formateur en een rooms-katholieke premier wellicht gewoonte zou worden. Overigens ging het er, volgens mr. Schokking, bij het noemen van de naam van De Geer niet om 'een partijgenoot als formateur aangewezen te zien'. Doch de uitslag der verkiezingen was zijns inziens een aanwijzing dat een eventueel optreden van Colijn niet zou leiden tot een gunstige atmosfeer. Maar al werd met het oog op de toekomstige samenwerking de voorkeur gegeven aan De Geer, dit betekende niet dat Colijn door de $\mathrm{CH}$ a priori werd uitgesloten.

De naam van Colijn als eventueel formateur werd ook genoemd door de liberale voorman $\mathrm{mr}$. H. C. Dresselhuys, maar slechts voor het geval dat er een coalitiekabinet zou komen als logisch gevolg van de stembusuitslag. Gezien de ervaringen met het ministerie-Ruys leek het hem zeer twijfelachtig dat er van een rechts bewind werkelijk vruchtbare en blijvende arbeid te verwachten viel. Zelf zag hij de coalitie als een 'irreëel en staatkundig ongezond verschijnsel'. Hij pleitte daarom voor een nationaal kabinet met als werkprogram 'de economische of finantieële reconstructie van den Staat' en gebaseerd op de partijen die aan dat doel wilden meewerken ${ }^{3}$.

Het is duidelijk dat een opdracht aan Colijn zijn sterkste motivering niet zou kunnen ontlenen aan dit liberale standpunt. Ook niet aan het uitgebrachte AR advies, dat weliswaar onomwonden Colijn aanbeval, maar tegelijk gebonden was aan de voorwaarde dat ook de andere rechtse partijen hem zouden aanwijzen. Aan die voorwaarde werd niet voldaan, althans niet door de christelijk-historischen. En van de democratische partijen (Vrijz. Dem. Bond en SDAP) was in geen enkel opzicht steun voor Colijn te verwachten. Als uitgesproken linkse groeperingen stonden zij oppositioneel tegenover de rechtse coalitie en diametraal tegenover de 'reactionaire' politiek die hij als minister van Financiën de laatste jaren had gevoerd.

Toch is het Colijn geworden. Ongetwijfeld heeft daartoe sterk bijgedragen de omstandigheid dat dr. W. H. Nolens, de leider van de rooms-katholieke en toenmaals grootste Kamerfractie, niet alleen al dadelijk de naam van Colijn had genoemd, maar zelfs diens benoeming nadrukkelijk had aangeraden. Op het eerste gezicht lijkt dit vreemd. Beter dan wie ook was Nolens op de hoogte van het gebrek aan eensgezindheid onder de coalitiegenoten, met name ten aanzien van het hete hangijzer: het Nederlandse gezantschap bij de paus. Onze vertegenwoordiging bij de Heilige Stoel was, vooral vanwege de bezwaren van christelijk-historische kant, telkens in de Kamer ter discussie gesteld. Dit vormde een meestentijds latente doch ernstige bedreiging voor een hechte en blijvende samenwerking tussen de gecoaliseerde partijen. Niettemin had Nolens vlak na de verkiezingen van 1 juli,

3. H. C. Dresselhuys aan H.M. de koningin, 8 juli 1925, dossier De V. 
zelfs buiten zijn fractie $\mathrm{om}^{4}$, geadviseerd tot een opdracht aan Colijn. Laatstgenoemde aarzelde en vroeg de koningin bedenktijd tot het voeren van besprekingen met Nolens en Schokking, als fractievoorzitters die het nauwst bij de gezantschapskwestie betrokken waren. Toen dit contact, waaromtrent ook de demissionaire minister dr. J. Th. de Visser werd ingelicht, niet tot het gewenste resultaat leidde, overwoog Colijn te bedanken. Maar daarmee zou - daarover was men het eens de formatie van een rechts kabinet van de baan zijn en ook, misschien zelfs definitief, de samenwerking der rechtse partijen ${ }^{5}$. Om nog een andere reden bleef Nolens het optreden van Colijn als de meest aanvaardbare oplossing beschouwen. De partij van Colijn vertoonde namelijk niet de antipapistische trekken die hij telkens bij de Christelijk Historische Unie had waargenomen. Desondanks durfde hij ook wel met de laatstgenoemde partij opnieuw in zee te gaan. Hij verwachtte dat ze een redelijk beleid zou voeren en meende bovendien zeker te weten, dat de inzichten van de $\mathrm{CH}$ Kamerclub niet door alle $\mathrm{CH}$ politici werden gedeeld. En wat de linkerzijde betrof was hij evenmin pessimistisch gestemd, omdat hij veronderstelde dat deze met enig overleg wel in het juiste spoor gehouden zou kunnen worden ${ }^{6}$.

$\mathrm{Al}$ deze overwegingen leidden ertoe dat Nolens ook in tweede instantie de koningin adviseerde Colijn tot de formatie uit te nodigen. Zijn raad werd opgevolgd, waarna Colijn toestemde. Van het begin af was de formateur zich ervan bewust dat een conflict in de naaste toekomst niet denkbeeldig was en dat een mogelijke opheffing van het gezantschap in Rome belangrijke politieke gevolgen kon hebben. Maar hij had liever een uiteengaan in de toekomst op grond van een openbaar conflict dan dat hij het nu zou laten afweten, zonder de gelegenheid te hebben de reden ervan uiteen te zetten vanwege het confidentiële karakter van de gehouden besprekingen ${ }^{7}$. En wellicht zou tijd raad brengen. De discrepantie tussen de coalitiegenoten op dit kritieke punt had immers tot dusver geen dramatische gevolgen gehad. Misschien ook zou althans één der betrokken partijen nog te rechter tijd terugschrikken voor de noodlottige consequenties van het veroorzaken van een kabinetscrisis. En de linkse groeperingen beschouwden de zaak niet als een principiële aangelegenheid, zodat onze vertegenwoordiging bij de paus tot nu toe zonder al te veel bezwaar gehandhaafd was.

4. F. J. F. M. Duynstee, 'De katholieke Tweede Kamer-fractie na 1918 uit haar notulen' in: Opstellen over recht en rechtsgeschiedenis aangeboden aan prof. mr. B. H. D. Hermesdorf (Deventer, 1965) 115.

5. P. J. Oud, Het jongste verleden. Parlementaire geschiedenis van Nederland(6 dln; Assen, 19481951) in, 36.

De delen I en II van dit werk behandelen de parlementaire geschiedenis van 1918-1925, waaraan hoofdzakelijk de gebeurtenissen en getallen in de 'Inleiding' zijn ontleend.

6. G. J. Lammere, De Kroon en de kabinetsformatie (IJmuiden, 1952) 98-99.

7. Mededeling van Colijn in de AR fractievergadering op 14 juli 1925. Zie dagblad De Standaard (maandag 22 maart 1926). 


\section{C. SUTTORP}

Ook de nauw bij de voorgeschiedenis der formatie betrokken politici hebben het risico durven nemen. Bij de beslissingen zal ook meegespeeld hebben de kwade herinnering aan de maandenlange crisis in 1923. Zo enigszins mogelijk moest ditmaal een soortgelijke impasse worden vermeden.

\section{VAL VAN HET KABINET COLIJN (1925)}

Al was dan de formatie na twee weken voltooid, de moeizame voorbereiding voorspelde niet veel goeds ${ }^{8}$. Weliswaar kende men elkaars standpunten en de voorafgaande jaren hadden bewezen dat, met enige goede wil tenminste, tegenstellingen overbrugd konden worden. Het zwakke punt bleef echter dat men, afgezien van onderlinge verschillen, ook afhankelijk was van de welwillendheid, onverschilligheid of tegenkanting der linkse partijen. Reeds een paar maanden later zou dit openlijk aan de dag treden.

De indiening van een schijnbaar onbelangrijk amendement op de begroting van Buitenlandse Zaken wierp de knuppel in het hoenderhok. De tweemansfractie der Staatkundig Gereformeerde Partij stelde bij het begrotingsdebat voor, de gelden voor het gezantschap bij de Heilige Stoel te schrappen. Het ging primair niet om een bezuiniging, die trouwens gering was (een bedrag van 28.000 gulden op de totale post 'Gezantschappen' van 1.262.220 gulden). Het ging de voorstellers om het principe. De fractieleider (ds. Kersten) noemde in zijn Kamerrede ${ }^{9}$ drie overwegingen. Hij zag in het gezantschap een erkenning van de geestelijke macht van de paus; voorts een versterking van de Roomse politiek; en in de derde plaats werd door dit gezantschap een Rooms cachet op het Nederlandse volk gedrukt.

Door dit amendement werden alle partijen gedwongen kleur te bekennen. Voor de rooms-katholieken was het een principiële kwestie, die langzamerhand zelfs een erezaak was geworden. De fractieleider Nolens legde duidelijkheidshalve terstond na de indiening een verklaring voor de Kamer af: dat opheffing van het gezantschap voor de katholieken 'uiterst grievend' zou zijn en dat bij aanneming van het amendement de rooms-katholieke Kamerleden ernstig zouden overwegen of zij hun stem zouden geven aan de begroting van Buitenlandse Zaken en of zij 'steun kunnen verleenen aan welk kabinet dan ook, voortgekomen uit groepen aan welker medewerking de opheffing van dezen gezantschapspost zou zijn te wijten' ${ }^{10}$. Het was een nogal ingewikkeld geformuleerde uitspraak, maar als waarschuwing duidelijk genoeg en met name voor de christelijk-historische Kamerleden een alle mis-

8. Tekenend in dit verband is het feit, dat de woordvoerder der SDAP (ir. J. W. Albarda) in de Tweede Kamer het optreden van Colijn 'aanmatiging van macht' en 'in strijd met de volkswil' heeft genoemd. Zie Handelingen van de Staten-Generaal, 1925-1926, 155 (5 november 1925).

9. Handelingen, 242 (10 november 1925).

10. Ibidem. 
verstand uitsluitende oproep tot bezinning. Deze groep kon er zich nog altijd niet bij neerleggen dat het in 1915 als tijdelijk bedoelde gezantschap na de oorlog permanent was gemaakt. Hun woordvoerder (J. R. Snoeck Henkemans) schoof dan ook alle verantwoordelijkheid af en legde deze in zijn rede bij degenen die indertijd dat gezantschap hadden doorgezet ${ }^{11}$. De AR fractie sprak zich ditmaal niet uit. Men erkende van die zijde het nut van de diplomatieke post en liet op dit punt zijn coalitiegenoten liever niet in de steek.

Voor de linkse partijen was het geen beginselkwestie, zelfs geen zaak van betekenis. De liberale fractie demonstreerde het ditmaal door er het zwijgen toe te doen. De woordvoerder der sociaal-democraten (W. H. Vliegen) kondigde aan dat zijn fractie zich vóór het amendement zou uitspreken, omdat men het gezantschap van 'geen enkel nut' beschouwde en omdat de vroeger bestaande redenen om vóór te stemmen er nu niet meer waren ${ }^{12}$.

Omstreeks het middernachtelijk uur kwam als laatste spreker daarna nog de minister van Buitenlandse Zaken zelf aan het woord. Hij wilde niet treden in een herhaling van hetgeen vroeger door hem was uiteengezet. Hij was nog steeds overtuigd van het nut van ons gezantschap in Rome, als 'bron van informaties' en hij eindigde zijn evenwichtig en allerminst alarmerend betoog met op te merken aangaande een opheffing ervan: 'Ik zie niet in, dat het landsbelang er door zou worden gebaat ${ }^{13}$. $\mathrm{Na}$ deze wederzijdse positiebepaling moest stemming over het voorgestelde amendement tenslotte de nodige duidelijkheid brengen. Maar in verband met het late vergaderuur werd het stemmen uitgesteld tot de volgende dag, woensdag 11 november 's middags om één uur. Het lot van de regering lag in handen van de linkse partijen. Vlak vóór de te houden stemming deed de vrijzinnig-democratische fractieleider (mr. H. P. Marchant) een opzienbarende mededeling. Zijn fractie achtte het gezantschap een vraag van 'zuivere opportuniteit' en het aan de orde gestelde amendement op zichzelf weinig belangrijk. Maar in dit geval ging het om een ver strekkende beslissing. Het voortbestaan van de coalitie was namelijk in het geding en om die reden zou men vóór het amendement stemmen ${ }^{14}$.

Zo was door de uitspraak van Nolens, de reactie van de CH Kamerfractie en de daarop inhakende verklaring van Marchant de schijnbaar zakelijke vraag van het al of niet handhaven van een gezantschapspost geworden tot een belangrijke politieke aangelegenheid die ingrijpende gevolgen kon hebben ${ }^{15}$. Des te merkwaardiger was het, dat noch door de minister van Buitenlandse Zaken noch door de ministerpresident de portefeuillekwestie of de kabinetskwestie werd gesteld.

11. Ibidem, 243.

12. Ibidem.

13. Ibidem, 244 .

14. Ibidem, 245.

15. J. A. de Wilde en C. Smeenk, Het volk ten baat (Groningen, 1949) 504-505. 


\section{C. SUTTORP}

$\mathrm{Na}$ alles wat er tevoren gezegd was kon de uitslag geen verrassing meer zijn: het amendement-Kersten werd aangenomen met 52 stemmen vóór. Alleen de roomskatholieken en de anti-revolutionairen (voor zover aanwezig) stemden tegen, zodat door deze twee partijen slechts 42 stemmen werden gehaald ${ }^{16}$. Het grootste deel van de 52 voorstemmers werd geleverd door de linkerzijde .Ook de $\mathrm{CH}$ Kamerleden stemden (afgezien van twee afwezigen) unaniem voor, zoals te verwachten was. Uiteraard viel de absentie van dr. de Visser, sinds kort voorzitter van de fractie, sterk op $^{17}$.

Prompt na de uitslag deelde de voorzitter van de ministerraad de Kamer mede, dat vier katholieke ministers hem hadden meegedeeld in de gegeven situatie ontslag uit hun ambt te zullen vragen. Tevens verzocht hij schorsing van de beraadslagingen over de staatsbegroting ${ }^{18}$. Aldus werd de basis onder het zittend kabinet weggeslagen. Een paar dagen later stelden ook de overige ministers hun portefeuilles ter beschikking. Het was duidelijk dat een aantal Kamerleden een onschuldig lijkend amendement hadden weten te hanteren als een breekijzer tegen de rechtse samenwerking.

Zo was binnen een half jaar het ministerie-Colijn gevallen. Velen in den lande vonden dit geen reden om te treuren. Vooral in linkse kringen verheugde men zich over de breuk in de coalitie. Dit kon wel eens, meende men, het definitieve einde van de traditionele politieke binding betekenen. Het was echter de vraag of er een realiseerbaar alternatief bestond. Voordat hierop een antwoord gezocht en gevonden kon worden moest eerst op zoek worden gegaan naar een competente formateur. Veel, zo niet alles, zou afhangen van de omstandigheid of dat iemand uit rechtse of uit linkse kring zou zijn.

Op grond van hetgeen zich had afgespeeld rond de kabinetscrisis werd vanzelfsprekend in eerste instantie de naam genoemd van mr. Marchant, die de bom onder het regerend kabinet had gelegd. De parlementaire regel zegt in zo'n geval: wie breekt moet betalen! Maar bij het stellen van de verantwoordelijkheid kon ook de naam van Nolens worden genoemd. Hij immers had getracht door zijn verklaring een bepaalde politieke beslissing te forceren en daarmee had hij weer anderen uitgedaagd. Ook de $\mathrm{CH}$ fractie ging dan niet vrijuit, want deze was ondanks de te voorziene kwalijke gevolgen onverzettelijk bij haar eigen standpunt gebleven. En kon

16. De bij de stemming afwezige leden waren: L. F. Duymaer van Twist (AR), H. Visscher (AR), P. Drooglever Fortuyn (lib.), J. E. W. Duys (soc.), J. Th. de Visser (CH) en H. W. Tilanus (CH). Zie J. R. Snoeck Henkemans, Parlementaire Herinneringen (s.1., s.a.) 44-46.

17. Voor De Visser was het een epineuze kwestie, daar hij zitting had in het kabinet dat vijf jaren tevoren de gezantschapspost blijvend had gemaakt. Volgens mededeling van Tilanus (zelf door ziekte verhinderd) was De Visser 'opzettelijk' afwezig. Zie G. Puchinger, Tilanus vertelde mij zijn leven (Kampen, 1966) 135.

18. Handelingen, 1925-1926, 246 (11 november 1925). 
Colijn zelf wel buiten schot blijven, die op goed geluk van wal gestoken was, terwijl de vooruitzichten op een voorspoedige vaart niet bepaald gunstig waren?

Deze en soortgelijke overwegingen zouden hun neerslag vinden in de adviezen die door de fractieleiders ter oplossing van de ontstane crisis aan de koningin werden uitgebracht. Het valt daarbij op dat de scheidingslijnen tussen die adviezen tamelijk grillig verliepen. Merkwaardig was ook dat door verscheidene adviseurs verantwoordelijkheid en formateurschap niet aan elkaar gekoppeld werden. Wie als 'breker' werd beschouwd kwam niet altijd voor 'betaler' in aanmerking.

De AR adviseur stond op het standpunt dat dr. Nolens door zijn verklaring op 10 november het politieke element in het debat gebracht had. Maar daar diens partij bij de stemming over het amendement in de minderheid gebleven was moest niet aan hem het formateurschap worden opgedragen. Ook niet aan de voorsteller van het amendement, want 'iedere aanwijzing ontbreekt omtrent den grondslag waarop eene Kabinetsformatie zijnerzijds zou kunnen rusten'. Dat laatste gold, meende hij, ook voor het Kamerlid Snoeck Henkemans, die de kabinetscrisis wel mede veroorzaakt maar niet begeerd had. En ook van de buitenspel staande liberale Vrijheidsbond kon geen constructieve bijdrage in deze gecompliceerde situatie worden verwacht. Vandaar dat hij de formatie wilde zien opgedragen aan mr. Marchant, die vóór de stemming nadrukkelijk had verklaard dat hij met politieke bedoeling het amendement zou steunen. Aan hem dus de taak om te tonen dat hij de verantwoordelijkheid voor het door hem opzettelijk in het leven geroepen gevolg aanvaard$\mathrm{de}^{19}$.

Opmerkelijk was de oplossing die de $\mathrm{CH}$ fractie voor ogen stond. Zonder voorafgaande toelichting poneerde de fractieleider, dr. De Visser, al bij het begin van zijn schriftelijk advies aan de koningin, dat de $\mathrm{CH}$ fractie van oordeel was dat het in 's lands belang zou zijn wanneer het kabinet-Colijn in zijn oorspronkelijke samenstelling zijn werkzaamheden zou kunnen voortzetten ${ }^{20}$. Dit was een verrassende uitspraak! Gemakkelijk gezegd, maar hoe gedaan? Op deze vraag had de fractie zich natuurlijk bezonnen en daarbij was men tot de volgende conclusie gekomen: afgezien van eventuele schijnoplossingen (een tijdelijk gezantschap of een gezantschapspost buiten bezwaar van de schatkist) was het voortbestaan van het demissionaire kabinet slechts mogelijk wanneer de rooms-katholieke bewindslieden terwille van het landsbelang terugkwamen op hun ontslagaanvrage. Men was intussen reëel genoeg om ook andere uitwegen te bedenken en aan te wijzen voor 't geval dat er aan deze voorwaarde niet zou worden voldaan. In de eerste plaats kon dan misschien een reconstructie van het kabinet plaatsvinden door de afgetredenen te vervangen door niet-rooms-katholieke ministers. Zou de formatie van zo'n rechts kabinet niet lukken, dan viel de vorming van een nationaal- of zakenkabinet te

19. Th. Heemskerk aan H.M. de koningin, 17 november 1925, dossier De V.

20. J. Th. de Visser aan H.M. de koningin, 19 november 1925, dossier De V. 


\section{C. SUTTORP}

overwegen, bestaande uit personen zonder een bepaalde politieke kleur en zich aandienend met een kort actueel program. En in het uiterste geval zou zelfs beproefd kunnen worden een kabinet samen te stellen uit alle politieke partijen (uitgezonderd de communisten) 'zoodat de boog zoo breed mogelijk wordt gespannen'. Dat men laatstgenoemd, nogal onwerkelijk aandoend voorstel, dat ook volgens de voorstellers zelf geen kans van slagen had, zwart op wit durfde stellen, is ongetwijfeld ingegeven door de wens om tot iedere prijs aan een uitgesproken linkse regering van vrijzinnig-democraten en sociaal-democraten te ontkomen. Dit was namelijk een eventualiteit die door de $\mathrm{CH}$ fractie ondubbelzinnig werd ontraden. Men achtte de kloof tussen deze partijen en de $\mathrm{CH}$ te groot en de basis voor een uitgesproken links kabinet te zwak.

Een geheel ander geluid deden de rooms-katholieken horen. Als inleiding op zijn advies aan de koningin gaf dr. Nolens een samenvattende reconstructie van de geschiedenis van het pauselijk gezantschap en de daarop gevolgde crisis $^{21}$. Op grond hiervan adviseerde hij, aan één der leiders van de vóór het amendement stemmende groepen de opdracht tot het vormen van een parlementair kabinet te geven. In de eerste plaats kwam zijns inziens daarvoor mr. Marchant in aanmerking. Hem speciaal was het erom te doen geweest het kabinet te doen vallen en daarom moest hij nu zelfzorgen voor een regering die steunde op een andere meerderheid. In dit advies klinkt duidelijk de echo op de regel: wie breekt betale!

Van liberale zijde werd door mr. Dresselhuys namens de fractie van de Vrijheidsbond vrij scherpe kritiek geleverd op de ontslagaanvrage van de rooms-katholieke ministers ${ }^{22}$. Daar was zijns inziens niet gehandeld in het belang van het land, maar met het oog op het partijbelang. Zijn uitvoerig advies bevatte nogal wat negatieve elementen die moesten illustreren, dat een rechtlijnige oplossing niet voor het grijpen lag. Om te beginnen achtte hij het ongewenst het thans demissionaire kabinet weer aan het bewind te brengen, omdat dan de eerbied voor het gezag bij ons volk in het gedrang zou komen en aan het ernstige karakter van een regeringscrisis te kort zou worden gedaan. Daar, vanuit zijn standpunt gezien, de zwaarste verantwoordelijkheid bij de katholieken lag, moest de vorming van een nieuwe regering eigenlijk in hun handen worden gelegd. Maar aangezien deze oplossing bij voorbaat tot mislukking gedoemd zou zijn, moest er naar een andere weg worden uitgezien. Een kabinet gebaseerd op de samenwerking van rooms-katholieken en anti-revolutionairen zou slechts een minderheidsregering zijn, kwalijk passend bij de politieke situatie van het ogenblik. En voor een regering van rooms-katholieken, sociaal-democraten en vrijzinnig-democraten achtte hij de tijd nog niet gekomen. Als beste, althans minst slechte oplossing resulteerde uit zijn overwegingen: een zaken-

21. W. H. Nolens aan H.M. de koningin, niet gedateerd, dossier De V. Blijkens de inhoud is de brief kort na 11 november geschreven.

22. H. C. Dresselhuys aan H.M. de koningin, 19 november 1925, dossier De V. 
kabinet van rechtse signatuur, met als eerst aangewezen formateur de heer Colijn. Deze keus motiveerde hij door er onder meer op te wijzen, dat deze politicus nog altijd het vertrouwen van de Kamer genoot en nog steeds in goede verhouding scheen te staan tot de drie coalitiegroepen. Een eventuele Kamerontbinding, waaromtrent de koningin zijn gedachten wenste te vernemen, wees hij resoluut af. Die oplossing zou naar hij meende geen verschuiving in de partijverhoudingen teweegbrengen, maar wel leiden tot verscherping van de geloofsverdeeldheid.

De laatstgenoemde veronderstelling werd gedeeld, naar blijken zal, door de socialistische adviseur, al wees deze overigens volstrekt andere wegen aan ter oplossing van de crisis. In de bespreking ten paleize Het Loo, op 18 november 1925, sprak ir. J. W. Albarda zich tegenover de koningin als volgt uit ${ }^{23}$. Allereerst achtte hij, gezien de gang van zaken, een voortbestaan van het ministerie-Colijn en zelfs de formatie van een ander coalitiekabinet onmogelijk. De breuk kwam namelijk niet voort uit de gezantschapskwestie alleen, maar hing samen met tegenstellingen binnen de coalitie die zich na het beëindigen van de schoolstrijd hadden doen gelden (onder andere ten aanzien van de sociale politiek, de defensie en de belastingpolitiek). Albarda sprak in dit verband van 'een gemis aan homogeniteit' en dit zou door een eventueel akkoord inzake het pauselijk gezantschap niet worden opgeheven. Een zuiver-links kabinet beschouwde hij als een onmogelijke zaak, zelfs als de linkse groeperingen over een meerderheid zouden beschikken. Daarvoor was de afstand tussen socialisten en liberalen te groot, terwijl bovendien een belangrijk gemeenschappelijk doel ontbrak. Als enige mogelijkheid zag hij een combinatie van katholieken, socialisten en vrijzinnig-democraten. Mits tegelijk een besliste koersverandering ten opzichte van het afgetreden coalitiekabinet zou plaatsvinden. Die verandering zou moeten inhouden: het beëindigen van de tot nu toe gevoerde reactionaire politiek. En dit zou zich moeten manifesteren in onder andere uitbreiding van de sociale voorzieningen en vermindering van de defensielasten. Kortom, in de verwerkelijking van een democratisch en vooruitstrevend program. Of de rooms-katholieken daaraan medewerking zouden willen verlenen was voor hem vooralsnog de grote vraag. In elk geval zou de formatie primair moeten worden toevertrouwd aan Nolens, de man die binnen die partij centraal stond en een overwegend aandeel had gehad in de gebeurtenissen die tot de crisis geleid hadden. Andere oplossingen, zoals een parlementair minderheidskabinet of een extra-parlementair kabinet zouden niet meer dan noodoplossingen kunnen zijn, waaraan slechts een korte duur en een zwak bestaan zouden beschoren zijn. En van een zogenaamd nationaal kabinet verwachtte hij slechts 'een karakterloosbeleid'. Ook een Kamerontbinding zou geen uitweg bieden. Integendeel, het zou leiden tot een godsdienststrijd met alle kwalijke gevolgen van dien.

23. J. W. Albarda aan H.M. de koningin, 19 november 1925, dossier De V. 


\section{C. SUÏTORP}

Rest tenslotte nog de politieke visie van de politicus die de breuk in de coalitie moedwillig had teweeggebracht, mr. Marchant. In zijn uitvoerig advies (het uitvoerigste van alle uitgebrachte adviezen!) gaf de fractieleider van de vrijzinnigdemocratische bond eerst een scherpe analyse van de politieke situatie ${ }^{24}$. En passant oefent hij daarbij bittere kritiek op het zogenaamde 'beleid-Colijn'. Terwijl de andere adviseurs erop hadden gewezen dat er in strikte zin geen conflict was tussen kabinet en Tweede Kamer was Marchant een geheel andere opvatting toegedaan. Op een typische manier maakte hij dit in zijn schrijven de koningin duidelijk. Wetend dat H.M. zelf van mening was, dat er eigenlijk geen conflict van die aard bestond, merkte hij 'eerbiedig' op dat er 'voor een andere opvatting ruimte is'. Zelf vond hij namelijk dat dit wel degelijk het geval was. Na een en ander breder te hebben uitgewerkt kwam hij tot de kernvraag: in welke richting moet de oplossing worden gezocht? Daarbij zag hij meer dan één mogelijkheid, althans in theorie. Na overweging van het vóór en tegen van die mogelijkheden (meerderheids-, minderheids-, nationaal kabinet) stelde hij als het verkieslijkst voor: een regering die steunde op een parlementaire meerderheid van rooms-katholieken, sociaal-democraten en vrijzinnig-democraten. Eerstgenoemde groep was hierbij onmisbaar, daar de twee democratische groeperingen slechts een minderheidskabinet zouden kunnen vormen; al zou dan, volgens hem, zo'n minderheid wel steun vinden in de meerderheid van het Nederlandse volk! Maar hun verantwoordelijkheid zou te zwaar worden en hun regeringsbeleid zou toch zijn aangewezen op de steun der katholieken. Een zekerder basis zou daarom worden gelegd indien zij als partners in het kabinet werden opgenomen. Hij meende dat deze meerderheidsformatie lag 'in de lijn van onze staatkundige ontwikkeling'. Gedecideerd en optimistisch voegde hij daaraan toe: 'Dit wordt thans vrijwel algemeen erkend'. Blijkbaar verwachtte hij niet (zoals Albarda) van rooms-katholieke kant op dit punt enige moeilijkheid. Wel van de 'conservatieve geesten' in den lande, maar hun bezwaren konden zijn inziens gemakkelijk worden ontzenuwd.

Als merkwaardigheid in Marchants adviesschrijven valt op, dat de uiteenzetting die aangevangen was met een 'Aan Hare Majesteit de Koningin' abrupt en zonder eerbiedsbetuiging eindigt met de ondertekening 'Marchant'. Slechts zijn socialistische collega tekent op bijna gelijke wijze met 'Het lid der Tweede kamer, J. W. Albarda'. Bij de andere adviseurs is de toon eerbiediger, hetgeen tot uiting komt in de enigszins gevarieerde, zij het traditionele ondertekening: 'Van Uwe Majesteit de getrouwe onderdaan' (Dresselhuys); 'Van Uwe Majesteit de gehoorzame dienaar' (Nolens); 'Uwer Majesteits onderdanige dienaar' (De Visser); 'Ik heb de eer

24. H. P. Marchant aan H.M. de koningin, 20 november 1925, dossier De V. Zie over de rol van Marchant ook: O. Vries, 'De Vrijzinnig-Democratische Bond als factor in de Nederlandse politiek (1917-1933)', Bijdragen en Mededelingen betreffende de geschiedenis der Nederlanden, LXXXVIII (1973) $461 \mathrm{vlg}$. 
te zijn van Uwe Majesteit de getrouwe onderdaan' (Heemskerk). De aanhef der brieven is bij vrijwel alle adviseurs gelijkluidend: 'Aan Hare Majesteit de Koningin'. Hierin vormt Heemskerk een opvallende (of toevallige?) uitzondering; hij zet boven zijn brief eenvoudigweg 'Aan de Koningin'.

Afgezien van deze formele kanten kunnen we ten aanzien van de inhoud der epistels betreffende het formateurschap het volgende vaststellen. Twee fracties bleven Colijn trouw (christelijk-historischen en liberalen); Nolens werd aanbevolen door de socialisten; Marchant door rooms-katholieken en anti-revolutionairen. Uitgerekend in Marchants advies werd niemand bij name genoemd. Dit kan erop wijzen dat hij wellicht zichzelf op het oog had. Deze indruk wordt versterkt door het feit, dat hij aan het slot van zijn brief verwijst naar zijn rede in de Tweede Kamer op 6 november, waarin hij 'in groote lijnen den aard van een regeeringsprogram' had aangegeven $^{25}$.

De uitspraak van de parlementaire geschiedschrijver ${ }^{26}$ dat de adviezen 'vrij algemeen' naar Marchant verwezen hebben, is gezien de zoeven vermelde gegevens, te weinig gefundeerd. Wel kan men stellen dat het advies van de grootste en bij de crisis meest betrokken partij (de rooms-katholieken) naast het anti-revolutionaire advies een extra gewicht in de schaal zal gelegd hebben. Was misschien de op te leggen 'betaling' bedoeld als straf voor de zonde van het 'breken' ? Of zag men in Marchant vooral de man, die het meest nadrukkelijk een volstrekt nieuwe weg aangewezen en zelfs aangeprezen had?

Hoe het ook zij, op 24 november werd aan Marchant de opdracht verleend. Onmiddellijk nam hij contact op met de leiders van de socialistische en de roomskatholieke partij. Het overleg strandde op de weigering van de katholieken om samen te werken met de socialisten, met het motief dat de diepere beginselen van de SDAP lijnrecht in strijd waren met de katholieke. Alleen 'bij uiterste noodzaak', aldus Nolens in zijn schrijven aan Marchant ${ }^{27}$ zou de katholieke fractie overgaan tot deze 'door haar zeer ongewenscht geachte samenwerking'. Zo kwam het dat Marchant al na een week zijn taak moest neerleggen ( 1 december). De formatie van een kabinet zoals hij zich dat had voorgesteld had geen schijn van kans nu de grootste fractie verstek liet gaan.

25. Blijkens een vertrouwelijke mededeling van de directeur van het kabinet der koningin aan Marchant zelf (zie Vries, 'De Vrijz. Dem. Bond', 462) is de brief bij Hare Majesteit slecht gevallen. Daartoe kunnen hebben bijgedragen zijn kritische toon, de vrijmoedige verwijzing naar een kant en klaar regeringsprogramma en de stereotiep stroeve ondertekening 'Marchant', zonder enige verdere plichtpleging.

26. Oud, Het jongste verleden, III, 67.

27. Geciteerd in P. J. Oud, Om de democratie (4 dln.; 's-Gravenhage - Assen, 1922-1933) $\mathrm{m}, 67$. 


\section{FORMATIEPOGINGEN VAN DE VISSER (1925-1926)}

Op 3 december 1925 werd dr. De Visser voor de volgende dag naar paleis Het Loo ontboden. $\mathrm{Nu}$ gebleken was, dat men aan een radicale vernieuwing van de politieke basis nog niet toe was, keerde men terug naar de oude, vertrouwde weg. De koningin verzocht de $\mathrm{CH}$ leider te bemiddelen tussen de rechtse groeperingen, als inleiding tot een formatie-opdracht. Een rechts kabinet zou immers pas mogelijk zijn wanneer de grondslag der samenwerking zou zijn hersteld. De Visser deelde de vorstin mede, dat hij reeds vóór haar uitnodiging officieus aan het werk was gegaan om, via een bespreking tussen de rechtse fractieleiders, de eenheid te herstellen. Hij verzocht daarom op deze weg te mogen voortgaan voordat er van een officiële opdracht sprake zou zijn.

Nog diezelfde dag stelde hij Nolens en Heemskerk voor, de volgende dag (5 december!) samen overleg te plegen over een te houden conferentie. Van dit plan werd ook de voorzitter van de ministerraad (Colijn) verwittigd. Dit laatste hield in, dat van het begin af Colijn betrokken werd bij de pogingen om tot een oplossing te geraken. Weldra zou blijken, dat hij er de man niet naar was om daarbij een passieve toeschouwersrol te vervullen.

Op maandag 7 december had in het Kamergebouw de beraamde conferentie plaats: de drie voorzitters en de drie ondervoorzitters der rechtse fracties. Op die bijeenkomst van zes verschenen: Nolens met mr. P. J. M. Aalberse, Heemskerk met dr. E. J. Beumer, De Visser met J. R. Snoeck Henkemans. Bij het aftasten der mogelijkheden bleek er slechts één praktisch bruikbaar: het terugroepen van de gezant in Rome en het accrediteren van een onzer gezanten (bijvoorbeeld die in Bern) bij de pauselijke Stoel ${ }^{28}$. Hiertegen bestonden bij de aanwezigen geen principiële bezwaren. Alleen de heer Snoeck Henkemans aarzelde nog.

$\mathrm{Na}$ over deze conferentie rapport te hebben uitgebracht aan de koningin kreeg De Visser op 8 december de opdracht om een parlementair kabinet samen te stellen. Uiteraard werden hiervan onmiddellijk Nolens, Heemskerk en ook minister Colijn op de hoogte gesteld. Tevens deelde de formateur mede, dat hij de christelijk-historische Kamerfractie zou polsen over de als mogelijk gestelde oplossing van de crisis.

Op 9 december had een fractievergadering plaats ten huize van De Visser. Tien leden waren aanwezig (één ontbrak er wegens ziekte), benevens de ministers De Geer en Schokking. Na ampele besprekingen stelde de voorzitter heel concreet deze vraag: of men bereid was een eventueel regeringsvoorstel, om een van onze ge-

28. De beide andere mogelijkheden (herstel van het tijdelijke gezantschap of een gezantschap buiten bezwaar van 's lands schatkist) werden door De Visser pro memorie vermeld, daar deze al eerder door de christelijk-historische fractie waren afgewezen. Trouwens ook de vertegenwoordigers der beide andere fracties zagen daarin geen heil. 
zanten te verbinden aan het pauselijk hof in Rome, te steunen. Slechts drie leden verklaarden zich daartoe bereid; één lid vroeg bedenktijd; de overige zes leden wensten zich alle vrijheid voor te behouden ${ }^{29}$. Een uitslag die weinig perspectief bood!

De volgende dag werd het verhandelde gerapporteerd aan Nolens, Heemskerk en Colijn. Laatstgenoemde had onmiddellijk zijn oordeel klaar: dat hij niet bereid was zich voor de tweede maal te wagen aan enige onzekerheid inzake de samenwerking der rechterzijde ten aanzien van het gezantschap.

Dit was weinig bemoedigend. Een poging om, via de minister van Buitenlandse Zaken, Colijn op dit punt tot andere gedachten te brengen had geen succes. Herstel van het coalitieverband en het aanblijven van het demissionaire kabinet schenen meteen illusoir.

De Visser gaf het echter nog niet op. Vrijdag 11 december stelde hij de christelijkhistorische Kamerleden voor in een motie hun teleurstelling uit te spreken, wanneer de regering met het voorstel zou komen om onze gezant in Bern op te dragen ons land bij het Vaticaan te vertegenwoordigen. Toen echter de anti-revolutionaire fractie daartegen een weliswaar formeel, doch onoplosbaar bezwaar had (men gaf aan de vorm ener 'verklaring' de voorkeur boven de motievorm) maakte hij van deze nooduitgang geen gebruik. Nog op de avond van diezelfde dag gaf hij in een persoonlijk onderhoud de koningin te kennen, dat hij van de vorming van een parlementair kabinet moest afzien. Op de vraag van H.M. welke andere mogelijkheden tot het beëindigen van de crisis nog openstonden, kon hij meedelen dat hij die middag nog van Nolens de pertinente verklaring had gekregen, dat de rooms-katholieke fractie 'onder geen beding' te vinden was voor een rooms-rode combinatie. Tevens verklaarde hij dat hij 'uit beginsel en uit het oogpunt van 's lands belang' zelf ook tegen deze oplossing adviseerde. Dit zo zijnde meende hij, dat thans een extra-parlementair kabinet het meest op zijn plaats zou zijn. Zo'n kabinet zou dan moeten zijn samengesteld uit vertrouwenwekkende figuren, werkende binnen een zogenaamde neutrale zone. Hij was van oordeel dat een dergelijk kabinet zou kunnen bijdragen tot een zekere politieke ontspanning.

Toen echter de volgende dag (12 december) bleek, dat de koningin de formatie van genoemd kabinet aan De Visser zelf wilde toevertrouwen, maakte hij daartegen bezwaar op grond van zijn Kamerlidmaatschap en fractievoorzitterschap. Om hieraan tegemoet te komen werd hem toen een andere, ruimere opdracht verleend: het vormen van 'een kabinet', zonder nadere specificatie. Hierop verklaarde hij, dat hij deze opdracht gaarne in beraad zou nemen.

Hij stelde zich voor te komen tot de vorming van 'een zelfstandig rechtsch kabinet, zonder officieel verband met de groepen in de Kamer'. Hiervan uitgaande richt-

29. J. Th. de Visser aan H.M. de koningin, 13 december 1925, dossier De V. 


\section{C. SUTTORP}

te hij 14 december een vertrouwelijk schrijven aan ieder van de afgetreden ministers met het verzoek in een zodanig kabinet zitting te willen nemen. Als oplossing van de gezantschapskwestie werd gesteld: opheffing van het afzonderlijke gezantschap bij het Vaticaan, maar accreditering van onze gezant in Bern bij de pauselijke Stoel, gezien het nationale belang dat de minister van Buitenlandse Zaken zag in onze vertegenwoordiging aldaar. Voorts zou een motie van afkeuring geen gevolgen hebben; maar ten aanzien van een motie van wantrouwen zou de kabinetskwestie gesteld worden. De formateur achtte intussen aanneming van 'een motie van de laatstbedoelde soort, menschelijkerwijs gesproken, uitgesloten ${ }^{\prime 30}$.

Positieve antwoorden op dit schrijven kwamen binnen van jhr. Van Karnebeek (Buitenlandse Zaken) en van jhr. De Geer (Binnenlandse Zaken). Ook de minister van Justitie (mr. Schokking) gaf, zij het met enig voorbehoud (namelijk dat van het gezantschap geen kabinetskwestie zou worden gemaakt) een bevestigend antwoord. Maar de ministers Colijn (Financiën) en Rutgers (Onderwijs) deden een heel ander geluid horen. Zij waren van oordeel dat de mogelijkheden tot het samenstellen van een parlementair kabinet nog volstrekt niet uitgeput waren. Zo was'bijvoorbeeld een kabinet van 'de uiterste noodzaak' (rooms-rood) nog niet beproefd, laat staan publiekelijk als mislukt bewezen. Daarna zou er nog plaats zijn voor de mogelijkheid van een extra-parlementair ministerie. Eerst als ook dit laatste niet gelukte, kon gedacht worden aan het overwegen van een terugkeer van de afgetreden ministers, meenden ze. Minister mr. Koolen (Arbeid) gaf, na een voorafgaand en door hem aangevraagd mondeling onderhoud, een schriftelijk antwoord, dat mede-ondertekend werd door zijn rooms-katholieke collega's ir. Bongaerts (Waterstaat), Lambooy (Oorlog) en Welter (Koloniën). Hun viervoudig antwoord (d.d. 18 december) kwam op het volgende neer. De demissionaire ministers kunnen zich niet verenigen met de terugroeping van de gezant, hetwelk ze beschouwen als 'een grievende bejegening'. Het afzonderlijke gezantschap dient te worden gehandhaafd, ook zonder dat daarvoor gelden op de begroting zouden worden uitgetrokken. Tenslotte verklaren ze zich bereid minister te blijven als ook alle andere collega's gehoor geven aan de uitnodiging.

Toen de formateur na het ontvangen van de reacties de balans ging opmaken kwam hij tot het volgende resultaat: de vier rooms-katholieke ministers hebben ten aanzien van het gezantschap een tegenvoorstel gedaan; de twee anti-revolutionaire ministers laten de gezantschapskwestie rusten, omdat ze eerst andere mogelijkheden van kabinetsformatie onderzocht willen zien; drie ministers (de partijloze minister van Buitenlandse Zaken en de twee christelijk-historische bewindslieden) gaan in 't algemeen akkoord. Hij meende thans eerst te moeten ingaan op het tegenvoorstel der katholieke bewindslieden. Daartoe ging hij besprekingen voeren met de andere

30. J. Th. de Visser aan H.M. de koningin, gedateerd 'Januari 1926', dossier De V. 
ministers. Enthousiast waren ze allerminst en ze opperden allerlei bezwaren, al gingen ze niet zo ver dat ze het voorstel geheel afwezen. Maar de formateur zelf had overwegend bezwaar tegen het voorstel. Het was hem namelijk bekend, dat de toenmalige gezant bij het Vaticaan slechts in het uiterste geval bereid was en dan nog slechts voor ten hoogste één jaar zijn post waar te nemen zonder daarvoor een tractement te toucheren ${ }^{31}$. Gewapend met deze wetenschap zag hij in de suggestie der rooms-katholieke ministers een verschuiving van het probleem, maar zeker niet de oplossing. Dit bracht hem ertoe tegenover mr. Kooien met beslistheid te verklaren, dat hun voorstel onaannemelijk was.

$\mathrm{Nu}$ de zaak aldus dreigde vast te lopen ging dr. Nolens zich ermee bemoeien. In een mondeling onderhoud op maandag 21 december drong hij er bij De Visser dringend op aan de formatiepoging nog niet op te geven. Een paar dagen later kwam bericht binnen, dat de katholieke ministers na onderling overleg - waarbij ook Nolens betrokken was- bereid waren de oplossing van de formateur (het accrediteren van onze gezant in Bern bij het Vaticaan) te accepteren, mits daarbij aan enkele voorwaarden werd voldaan. Het ging hun er vooral om dat er zekerheid gegeven werd, dat de christelijk-historische Kamerfractie geen spaak in het wiel zou steken door te stemmen vóór moties of amendementen welke de zaak weer op losse schroeven zouden zetten.

Thans was het woord weer aan de christelijk-historische Kamerleden. Reeds de volgende dag ( 24 december) kwamen de fractieleden (op één na) bijeen. Ook de beide christelijk-historische ministers en de waarnemende voorzitter der partij (prof. Slotemaker de Brü̈ne) woonden de vergadering bij, op verzoek van de formateur. Hij besefte het gewicht der te nemen beslissingen. De teneur der besprekingen was niet onwelwillend tegenover de suggesties der katholieke ministers. Men had waardering voor hun bereidheid tot het brengen van een offer door akkoord te gaan met de zogenaamde Bern-oplossing. Het verloop der discussies gaf de voorzitter de overtuiging dat zo goed als alle leden hun stem aan eventuele moties van wantrouwen zouden onthouden.

Van dit verheugende resultaat stelde hij in zijn schrijven d.d. 25 december de voorzitter van de ministerraad op de hoogte. Maar het per omgaande ontvangen antwoord moet de volijverige formateur hebben geschokt. Colijn vroeg namelijk 'eenige nadere opheldering' en uit deze woorden sprak duidelijk een zekere ongerustheid. Het ging hem vooral om de uitdrukking 'zo goed als alle leden' en om het begrip 'hun stem onthouden'. Deze formuleringen lieten zijns inziens te veel speelruimte.

31. Dit was gebleken uit een schrijven van onze pauselijke gezant in Rome'(jhr- mr. O. van Nispen tot Sevenaer) d.d. 7 december 1925 aan Colijn. Laatstgenoemde had namelijk bij de gezant voorzichtig geïnformeerd, hoe deze dacht over het vervullen van zijn functie zonder dat daarvoor een bedrag op de begroting zou worden geplaatst. Via de minister van Buitenlandse Zaken had De Visser de brief van de gezant onder ogen gekregen (Afschrift hiervan in dossier De V.). 


\section{C. SUTTORP}

En de briefschrijver vroeg zich ook af, of men wel voldoende aandacht had geschonken aan nog andere mogelijkheden die tot moeilijkheden aanleiding zouden kunnen geven. Het ging hem erom meer zekerheid te krijgen en een antwoord op korte termijn, daar de kwestie over een paar dagen in de ministerraad ter sprake zou komen ${ }^{32}$.

Thans was het weer zaak voor de formateur via enige opheldering de gevraagde zekerheid te verschaffen. Hij deed een poging daartoe in een brief die hij nog juist op maandag de 28ste (de dag waarop de ministerraad zou vergaderen) de premier kon doen toekomen. Veel had hij echter aan zijn vroegere schrijven niet toe te voegen. De term 'zo goed als alle leden' moest in deze zin worden verstaan, dat 'de meerderheid' beslist zou stemmen tegen moties van wantrouwen, maar dat 'enkele anderen' zich daarbij hun vrijheid voorbehielden. En wat het begrip 'onthouden' betreft, daarover was in de vergadering niet nader gesproken, evenmin als over andere door Colijn aan de orde gestelde eventualiteiten. Verder sprak uit zijn brief vertrouwen in de toekomstige ontwikkeling, op grond van de geest die in de fractievergadering had geheerst ${ }^{33}$.

De ministerraad dacht er echter anders over. De voorzitter moest de formateur dan ook berichten, dat diens opvattingen en geruststellende bewoordingen bij de ministers de onzekerheid niet hadden kunnen wegnemen ${ }^{34}$. Integendeel, het laatste schrijven van de formateur had de bestaande twijfel eerder versterkt dan verzwakt en 'meer licht' werd dan ook volstrekt nodig geoordeeld. Het voorstel tot het accrediteren bij het pauselijk hof van een gezant buiten Italië had weliswaar genade gevonden in de ogen van de ministerraad, doch slechts voorlopig, daar eerst de rooms-katholieke en de anti-revolutionaire Kamerfractie er nog in gekend moesten worden. Maar het centrale punt was, dat men alsnog door de formateur ervan overtuigd wilde worden, dat een kabinet volgens zijn opzet levensvatbaar zou zijn, zonder het risico te lopen van een herhaling der vroegere moeilijkheden.

Ondanks het in genoemd schrijven aan de dag tredende scepticisme was de formateur allerminst uit het veld geslagen of ontmoedigd. Hij verheugde zich erover dat alle ministers zijn voorstel tot regeling van de gezantschapskwestie accepteerden. Restte slechts het verschaffen van nog meer zekerheid en deze ging hij opnieuw zoeken bij de christelijk-historische fractie. Op de middag van de 30ste december kwam een achttal Kamerleden bijeen en ook nu was het eerder genoemde drietal aanwezig. Daar kwam men overeen dat de christelijk-historische fractie zelf een motie zou

32. H. Colijn aan J. Th. de Visser, 26 december 1925, dossier De V.

33. Een lid der fractie (J. R. Snoeck Henkemans) verklaarde later in de Kamer, dat vijf van de tien leden zich hun 'absolute vrijheid' hadden voorbehouden. Zie Handelingen, 1925-26, 341 (12 maart 1926). Niet ten onrechte werd De Visser door het Kamerlid Heemskerk een 'optimist, met de beste bedoelingen' genoemd (Ibidem, 335).

34. H. Colijn aan J. Th. de Visser, 29 december 1925, dossier De V. 
indienen. De hoofdstrekking van de door De Visser zelf ontworpen motie ${ }^{35}$ was, dat men niet zijn afkeuring maar slechts zijn 'teleurstelling' (het vroegere idee van De Visser!) wilde uitspreken over het feit, dat in de regeling van de gezantschapskwestie niet tegemoetgekomen was aan de 'principiële' bezwaren van de christelijkhistorische Kamerleden. De aanwezigen gingen unaniem akkoord met de inhoud der motie. Op de vraag of men, als de motie werd voorgesteld, ook bereid was tegen alle andere moties te stemmen, antwoordde men bevestigend, met uitzondering van twee leden die zich hun vrijheid wensten voor te behouden. Ingewikkelder lag het met eventueel door andere Kamerleden voor te stellen principiële amendementen (tegen de reis- en verblijfkosten van de geaccrediteerde gezant). Men zou tegen die amendementen stemmen indien de eigen motie werd verworpen; maar bij aanneming der motie wenste men geheel vrij te staan. Zo bleef er nog allerlei onzekerheid in de afspraken, welke bovendien gemaakt werden door een fractievergadering die onvoltallig was. Desondanks bleef de formateur optimistisch. Zijn vertrouwen was gegrond op de veronderstelling dat de in te dienen motie in de Kamer toch geen meerderheid zou halen.

Nog diezelfde dag schreef hij een brief aan de voorzitter van de ministerraad om hem de tekst van de motie van teleurstelling mee te delen en hem op de hoogte te brengen van de plannen en besluiten. Hij voegde eraan toe, dat het hem 'zoo goed als zeker' voorkwam dat van aanneming der motie geen sprake zou zijn, omdat de linkerzijde er niet vóór zou stemmen daar er van die kant nimmer 'principiële' bezwaren waren geopperd zoals van christelijk-historische zijde in de motie werden aangegeven. Verder ging hij ervan uit dat de anti-revolutionairen en de roomskatholieken zich bij de houding der christelijk-historischen zouden neerleggen. Op grond van dit alles geloofde hij dat de coalitieband er hechter door zou worden en dat het kabinet rustig zijn werk zou kunnen voortzetten. Tenslotte zag hij in deze ontwikkeling een laatste mogelijkheid voor een rechts kabinet.

Binnen de kortst mogelijke tijd gaf Colijn daarop antwoord. In een brief d.d. 31 december 1925 rekende hij De Visser voor, dat in werkelijkheid slechts op zes leden der christelijk-historische fractie kon worden gerekend. Maar wat veel ernstiger was: volgens de ministerraad liep de christelijk-historische motie wel degelijk kans om te worden aangenomen. En dit zou inhouden dat de christelijk-historische fractieleden dan vrij stonden tegenover eventuele amendementen die de oplossing van de gezantschapskwestie konden frustreren.

Aldus in het nauw gedreven, moest de formateur in zijn schrijven van nieuwjaarsdag 1926 toegeven, dat er 'een gering element van onzekerheid' bleef bestaan. Hij legde daarbij sterk de nadruk op het woordje 'gering', omdat hij zich een-

35. In het dossier De V. bevindt zich een getypt concept met enkele geschreven correcties van de hand van De Geer. Deze zwakte de al te scherpe veroordeling van de politieke motieven bij het votum van 11 november af door een vagere formulering, welke door De Visser werd overgenomen. 


\section{C. SUTTORP}

voudig niet kon voorstellen dat de linkse partijen vóór de motie zouden stemmen. Hij achtte het echter overbodig en ongewenst nogmaals met de leden der fractie te overleggen, omdat reeds het uiterste was bereikt en, naarmate de crisis langer duurde, de stemming in de groep er niet beter op werd. Hij bekende dat niet allen het eens waren met de door hem gevolgde weg. Maar het bereikte resultaat bewees, dat men prijs stelde op bestendiging van de rechtse samenwerking. En het zou met het oog op 's lands belang dubbel te betreuren zijn, indien het zittend kabinet verdween en de coalitie zou worden verbroken, aldus de formateur aan het slot van zijn brief. In zijn antwoordschrijven berichtte de voorzitter van de ministerraad onder andere het volgende ${ }^{36}$. De onzekerheid is nog niet weggenomen. Maar ook de ministers zijn van mening, dat er alles aan gelegen is de rechtse samenwerking en een rechts kabinet te behouden. Daarom is de ministerraad bereid het voorstel te accepteren onder dit voorbehoud: dat het kabinet de vrijheid zal hebben eventuele amendementen te beschouwen als motie van wantrouwen en met dezelfde consequenties. Bovendien zal ook het 'welnemen' moeten worden gevraagd van de heren Nolens en Heemskerk over de te nemen beslissing.

Het valt op, dat niet De Visser, maar Colijn zich in dit verband tot Nolens en Heemskerk ging richten. Zelfs ging hun correspondentie buiten de formateur om, al kreeg hij wel de afschriften van de brieven toegezonden. Hij had zich tot taak gesteld de bestendiging van het ministerie-Colijn en wenste zich in zijn schriftelijk overleg te beperken tot de demissionaire ministers op wier steun hij geheel was aangewezen. Dat hij daarbij geregeld mondeling besprekingen voerde met de christelijkhistorische Kamerleden lag voor de hand. Hij was nu eenmaal leider van de fractie die in de gezantschapsaffaire een sleutelpositie innam.

De ministerraad wilde alvorens definitief te beslissen volstrekte zekerheid hebben. Deze kon De Visser niet geven. Wat eraan ontbrak, konden de beide andere rechtse fracties aanvullen door duidelijk positie te kiezen. In twee vrijwel gelijkluidende brieven stelde Colijn beide fractievoorzitters op de hoogte van de stand van zaken, onder overlegging van zijn correspondentie met de formateur ${ }^{37}$. Aan het slot van zijn brief informeerde hij of de twee rechtse fracties 'in hun geheel' het kabinet zouden steunen, nu dit bereid was de voorstellen van dr. De Visser (het aanblijven van de ministers en het accrediteren van een gezant van elders bij het Vaticaan), zij het voorwaardelijk (het stellen van de kabinetskwestie tegenover eventuele amendementen en de volledige steun van de beide rechtse fracties) te aanvaarden.

Het wachten was nu op de reacties van de rooms-katholieke en anti-revolutionaire fractie. Eerst ontving de voorzitter van de ministerraad een schrijven van dr. Nolens, namens de Kamerclub ${ }^{38}$. Daarin werd de vraag gesteld of het kabinet zou

36. H. Colijn aan J. Th. de Visser, 5 januari 1926, dossier De V.

37. H. Colijn aan W. H. Nolens en Th. Heemskerk, 5 januari 1926, dossier De V.

38. W. H. Nolens aan H. Colijn, 8 januari 1926, dossier De V. 
aanblijven als een 'parlementair kabinet' of als een 'zelfstandig rechts kabinet'. Deze vraag betekende meer dan een kwestie van naamgeving. In het eerste geval zou namelijk de verhouding tussen kabinet en rechtse partijen van vóór 11 november 1925 worden hersteld en behoefden de ministers slechts op hun ontslagaanvrage terug te komen. Daarmee zou de koningin buiten de oplossing van de crisis kunnen blijven. Verder vroeg hij nog, in hoeverre de houding der christelijk-historische fractie zekerheid gaf ten aanzien van amendementen en moties betreffende het gezantschap. Immers van de rooms-katholieke en anti-revolutionaire fractie werd verlangd dat zij het kabinet 'in hun geheel' zouden steunen.

Het schrijven van mr. Heemskerk ging wat uitvoeriger op de zaken in $^{39}$. De antirevolutionaire Kamerclub was van mening dat een christelijk-historische motie van teleurstelling wèl aangenomen zou worden. Als de christelijk-historischen niet verder over de brug kwamen zou een deel van die partij toch nog een nieuwe crisis kunnen veroorzaken. Hun tegemoetkoming bestond hierin, dat zij een motie willen voorstellen waarvan zij hopen dat die zal worden verworpen! 'Dit achten wij', aldus Heemskerk, 'onwaarachtig en geheel vicieus'. Voorts stonden de anti-revolutionairen nog altijd op het standpunt dat niet alle oplossingen waren beproefd en dat de vorming van een extra-parlementair ministerie kans van slagen had. Daarom kon de fractie, met alle waardering voor de goede bedoelingen van de formateur, zich niet verenigen met de voorgestelde oplossing. Een verdediging van die oplossing, aldus de conclusie, was dan ook van anti-revolutionaire kant niet te verwachten. Slechts Nolens' brief vereiste een antwoord, omdat daarin een paar vragen werden gesteld. Op de eerste vraag (omtrent het karakter van het kabinet) antwoordde Colijn in zijn brief van 11 januari 1926, dat naar het oordeel van de formateur de verhouding tussen kabinet en rechtse partijen (als tenminste zijn poging slaagde) materieel niet, maar formeel wel zou worden gewijzigd. Het zou dus niet blijven wat het vóór 11 november geweest was. Wat de andere vraag betrof (over de zekerheid die de christelijk-historische fractie al of niet bood) kon Colijn niet verder gaan dan eraan te herinneren, dat de christelijk-historische Kamerclub geen 'besluit' daaromtrent had genomen. De zekerheid berustte op gesprekken tussen de formateur en leden van de club.

Het lag in de lijn dat dit informatieve schrijven niet voor honderd procent de verlangens der rooms-katholieke fractie bevredigde. Niettemin accepteerde men 'de op zichzelf niet zeer gewenschte oplossing'. Doch aan deze bereid verklaring werden enkele voorwaarden verbonden die de bedoeling hadden de vrijheid der christelijkhistorische Kamerleden in te perken. Van die kant, aldus verlangde Nolens namens zijn fractie, zou geen steun mogen worden verleend aan moties of amendementen tot schrapping van gelden voor het gezantschap. Evenmin mocht door hen een

39. Th. Heemskerk aan H. Colijn, 9 januari 1926, dossier De V. 


\section{C. SUTTORP}

motie van teleurstelling worden voorgesteld; hoogstens een 'verklaring' waarin teleurstelling wordt geuit in een voor het kabinet acceptabele vorm. En tenslotte moest door de christelijk-historische fractie eenzelfde uitspraak worden gedaan als van de beide andere rechtse fracties was verlangd inzake het aanvaarden van de voorgestelde oplossing.

Van de gevoerde correspondentie bracht de premier verslag uit aan de formateur ${ }^{40}$. Hij gaf daarbij te verstaan, dat alles nu afhing van de christelijk-historische fractie. En veelzeggend voegde hij daaraan toe: 'Het zou te betreuren zijn, indien de oplossing waaraan door $\mathrm{U}$ in 's Lands belang zooveel moeite en tijd zijn besteed, in dit stadium nog zou stranden'.

De formateur consulteerde daarop nogmaals enkele leden van de christelijk-historische fractie. Waarom heeft hij niet, kan men vragen, juist in die beslissende eindfaze al zijn fractiegenoten in het overleg betrokken? Achteraf heeft hij 'daarover de volgende verklaring gegeven ${ }^{41}$ : 'De anderen in dien korten tijd te bereiken, was niet mogelijk en ook niet noodig, omdat hun gevoelen mij zoowel uit vroeger onderhoud als uit persoonlijke brieven voldoende bekend was'. Al spoedig werd het hem duidelijk dat de zaak, die hij voorstond en waaraan hij zo veel energie en tijd had besteed, niet haalbaar was. Zijn fractiegenoten stonden afwijzend tegenover de voorwaarden der rooms-katholieke fractie, omdat ze van mening waren dat er reeds zeer veel concessies waren gedaan om een compromis te bereiken. Men voelde er niets voor om de motie af te zwakken door een verklaring. En men weigerde zich als fractie te binden ten aanzien van eventuele amendementen. Men verzocht daarom De Visser aan de voorzitter van de ministerraad een afwijzend schrijven te richten. Te gereder deed de fractieleider dit omdat Colijn hem in een persoonlijk gesprek had meegedeeld, dat de brief van mr. Heemskerk het hem moeilijk maakte het compromis te aanvaarden. Heemskerk had immers aan het slot van zijn schrijven duidelijk te kennen gegeven, dat zijn fractie het niet eens was met de manier waarop de crisis zou worden opgelost.

De zaak liep dus van meer dan één kant hopeloos vast. Er ging dan ook de 15de januari een brief van De Visser naar Colijn met de onheilspellend klinkende aanhef: 'Mijn antwoord op Uwer Excellentie's schrijven van 14 januari j.1. kan zeer kort zijn'. Het schrijven bevatte de mededeling, dat de christelijk-historische Kamerleden weigerden te treden in de door de rooms-katholieke fractie gestelde condities. Hieruit volgde, aldus de schrijver, dat er van een zogenaamd zelfstandig rechts kabinet geen sprake meer kon zijn. En hij besloot zijn brief met het uiten van zijn grote waardering voor 'de wijze, waarop Uwe Excellentie en Uwer Excellentie's ambtgenooten mijn voorslag hebben ontvangen en tot het einde toe hebben bejegend'.

40. H. Colijn aan J. Th. de Visser, 14 januari 1926, dossier De V.

41. J. Th. de Visser aan H.M. de koningin, gedateerd 'Januari 1926', dossier De V. 
De gang van zaken had bewezen dat het toenmaals niet mogelijk was met eenvoudige middelen tot een oplossing van de crisis te geraken. Door het gebeurde waren de partijverhoudingen danig vertroebeld. Daar kwam bij, dat in de behandeling van de impasse voor de tijdgenoten veel onduidelijk bleef. Volgens het christelijk-historische Kamerlid H. W. Tilanus, die de ontwikkeling van zeer nabij meemaakte, zijn er weinig crises zo vermaard geweest om de 'geheimzinnige onoplosbaarheid' als deze ${ }^{42}$. De liberale woordvoerder mr. Dresselhuys sprak in de Kamer van 'afkeurenswaardige sluiers der geheimhouding' en de socialistische fractieleider ir. Albarda uitte een gelijksoortige klacht ${ }^{43}$.

Achteraf heeft men getracht de verantwoordelijkheden zo duidelijk mogelijk te stellen. Midden maart 1926, toen de kabinetscrisis definitief was beëindigd, heeft men een retrospectieve Kamerdiscussie gewijd aan de vroegere formatiepogingen. Vanuit verschillende standpunten werden enkele van de hiervóór gereleveerde, maar voor de toenmalige Kamerleden nog onbekende feiten aan de publiciteit prijsgegeven. Dat er niettemin verschil van interpretatie van het gebeurde mogelijk was, bleek duidelijk op één punt: de vraag hoe en wanneer de christelijk-historische Kamerleden waren ingelicht over de plannen van de vier rooms-katholieke bewindslieden, welke op 11 november 1925 waren uitgevoerd ${ }^{44}$. De verklaringen van de rooms-katholieke en de christelijk-historische woordvoerder (respectievelijk Nolens en Snoeck Henkemans) stonden hier diametraal tegenover elkaar. Achteraf mag men als conclusie stellen, dat de christelijk-historische fractie tijdig op de hoogte kan geweest zijn. Zo dit niet het geval geweest is moet er een onbegrijpelijke communicatiestoornis tussen leiding en leden der fractie hebben plaats gehad ${ }^{45}$.

Bij de gecompliceerdheid der situatie kan men moeilijk spreken van aperte schuld, al werden er wel schuldigen verondersteld en aangeduid. De rooms-katholieken konden aan de christelijk-historischen verwijten, dat ze al in het begin willens en wetens de samenwerking van rechts onmogelijk hadden gemaakt, door voor het amendement-Kersten en impliciet tegen het gezantschap bij de paus te stemmen. Omgekeerd kon men van christelijk-historische kant erop wijzen, dat de katholieken van die zaak een prestigekwestie hadden gemaakt en daarom zo onverzettelijk hadden vastgehouden aan het eenmaal bereikte.

Aan de linkse partijen kon men voorhouden, dat er onverwachts een tactische

42. Puchinger, Tilanus, 135.

43. Handelingen, 1925-26, 351 (16 maart 1926) en 330 (12 maart 1926).

44. Ibidem, 375-379 (17 maart 1926) en 405 (18 maart 1926). Nolens' uitspraken in de Kamer betreffende het verschaffen van inlichtingen komen overeen met zijn (reeds genoemd) ongedateerd verslag aan de koningin.

45. Ook het verslag in De Standaard van 22 maart 1926 ('door relatie met den heer Colijn daartoe beter in staat dan eenig ander') bevestigt nadrukkelijk en in details, dat althans de voormannen tijdig en meermalen op de hoogte zijn gesteld. Overigens ging het hier om een formele kwestie, daar niet kan worden aangenomen dat de houding der christelijk-historischen op dit punt voor ingrijpende wijziging vatbaar was. 


\section{C. SUTTORP}

manoeuvre was toegepast om de rechtse coalitie te ondermijnen en aldus voor zichzelf politieke winst te behalen. De liberalen hebben getracht bij de behandeling van de schuldvraag buiten schot te blijven. Weliswaar hadden ze ook vóór het beruchte amendement gestemd, maar volgens hun woordvoerder in de Tweede Kamer was dat gebeurd op zuiver-zakelijke gronden. Het was hun er niet om te doen geweest het kabinet-Colijn te doen vallen. Maar zij wensten de rooms-katholieke 'partijeisch en dus als bedreiging' afgelegde verklaring niet te aanvaarden. Ze wilden liever voorbijgaan aan wat ze beschouwden als een' coalitiekibbeling ${ }^{\prime 46}$.

Verschil van mening kan er ook zijn over de vraag, welke partij het minst heeft bijgedragen tot de oplossing van de crisis nadat deze in november 1925 een feit geworden was. De katholieken, omdat ze in 't zicht van de haven nog allerlei voorwaarden waren gaan stellen? De christelijk-historischen, die hardnekkig bij hun standpunt gebleven waren, terwijl ze slechts een beperkte ruimte open lieten voor een compromis? De anti-revolutionairen, die de lange en onzekere weg van andersoortige oplossingen verkozen boven de korte en voor de hand liggende welke hun gewezen werd?

Of moet men zich beperken tot bepaalde personen die nauw bij het formatieproces betrokken waren? Bij voorbeeld tot de ministers zelf, die geen enkel risico durfden te nemen na de opgedane ervaringen? Of tot mr. Marchant als formateur, die blijkens de negatieve uitslag zich schromelijk vergiste in de mogelijkheid om de politieke koers drastisch te wijzigen? Of bij de tweede formateur, die al te lang vasthield aan eigen ideeën en daarbij een nogal omslachtige procedure volgde?

Midden in de onzekerheid en na alles wat er reeds gebeurd was, werd de formatieprocedure nog nodeloos verlengd tengevolge van een nieuw verzoek dat dr. De Visser van de koningin ontving: het samenstellen van een extra-parlementair ministerie. Daarop was meer dan eens van anti-revolutionaire zijde aangedrongen en het is dan ook niet onwaarschijnlijk dat de suggestie thans was uitgegaan van.Colijn zelf. Vandaar dat De Visser de vraag richtte tot de leider van de anti-revolutionaire fractie of hij de formatie van een extra-parlementair kabinet in overweging zou willen nemen. Heemskerks antwoord was kortaf weigerend en werd aldus gemotiveerd: 'Ik zou daardoor in een scheeve positie komen zonder uitzicht 's lands belang te dienen'. Dat was wel duidelijk, maar verder commentaar ontbrak.

Vervolgens wendde De Visser zich tot jhr. De Geer. Hij stond niet onwelwillend tegenover het verzoek. Maar toen een paar gegadigden, na gepolst te zijn, bedankten gaf ook deze het op ${ }^{47}$.

46. Handelingen, 1925-26, 351 (16 maart 1926).

47. J. Th. de Visser aan H.M. de koningin, 22 januari 1926 (dossier De V.). Een enigszins andere lezing bij Oud, Het jongste verleden, III, 70 (in aansluiting op een verklaring van jhr. De Geer in de Tweede kamer op 18 maart 1926). 
$\mathrm{Nu}$ er geen plaats bleek te zijn voor een rechts extra-parlementair kabinet waren De Visser en De Geer van oordeel, dat verdere pogingen geen zin hadden en dat er thans ruimte gemaakt moest worden voor een extra-parlementair kabinet 'onder linksche signatuur'. Daartoe opende eerstgenoemde besprekingen met mr. Limburg (vrijzinnig-democraat, lid van Gedeputeerde Staten van Zuid-Holland en oudlid van de Tweede Kamer). Op grond van dit overleg vestigde hij bij de koningin de aandacht op de heer Limburg als mogelijk formateur. Zijn aanwijzing werd opgevolgd en enkele dagen later begon Limburg aan zijn opdracht ${ }^{48}$.

Inmiddels was De Vissers taak als formateur officieel beëindigd. Bij schrijven van de directeur van het kabinet der koningin, gedagtekend 22 januari 1926, werd hem ontheffing verleend van de opdracht van 12 december 1925. Op deze mededeling volgden de woorden:

Hare Majesteit heeft mij opgedragen hieraan toe te voegen, dat Hoogst Dezelve de wijze waarop $\mathrm{U}$ zich met terzijdestelling van persoonlijke overwegingen en belangen aan uwe moeilijke taak hebt gewijd, zeer heeft gewaardeerd.

De vererende woorden, van die zijde geuit, kunnen de diepe teleurstelling bij De Visser over het niet-slagen hebben getemperd, een teleurstelling was en blééf het. Zeven jaar had hij als hoogste dienaar der Kroon het land gediend. Dat was lang genoeg geweest om de bijna zeventigjarige verdere ambities in die richting te ontnemen. Maar hij kon er zich moeilijk bij neerleggen dat alle moeite om de rechtse partijen bijeen te houden tevergeefs was geweest. Want de bestendiging van de samenwerking in coalitieverband had hij als zijn voornaamste taak beschouwd.

Men kan er verschillend over denken of zijn volhouden op dat punt stoer of alleen maar koppig was. En of hij niet té lang had vastgehouden aan een bepaalde oplossing die hem - niet als de gemakkelijkste, maar als de beste - voor ogen stond. Het beraad met zijn niet altijd gewillige fractiegenoten moet hij nu en dan als een rem hebben gevoeld, zodat de onderlinge verhouding er wel onder lijden moest. Binnen die kring zag men in zijn bezigheid een al te hardnekkig streven om volgens een bepaald plan de crisis op te lossen ${ }^{49}$.

Het einde van zijn formatiepogingen betekende (voorlopig of definitief, dat was toen nog niet te voorspellen) de afsluiting van een min of meer stabiele periode in de landspolitiek. Blijkbaar moest men nu een geheel andere richting inslaan, door wie dan ook gewezen. En daarvan viel moeilijk te zeggen waarop dat zou uitlopen: weer op de oude, bekende weg of op een geheel nieuwe. In elk geval sloeg men nu een omweg in, zoals achteraf gebleken is.

48. Ibidem, 70-71.

49. Puchinger, Tilanus, 136-137. 


\section{NIEUWE WEGEN (na 1926)}

De weg die mr. Limburg insloeg leidde niet tot een bruikbare oplossing. Nieuwe formateurs na hem volgden andere wegen, maar kwamen spoedig (één zelfs binnen een dag!) tot de ontdekking, dat ook die doodliepen.

Plotseling werd men voor een fait accompli gesteld: een door De Geer geformeerd kabinet, in alle stilte voorbereid en op korte termijn tot stand gebracht (maart 1926). Het was slechts bedoeld als een intermezzo-kabinet, een tussentijdse oplossing om de wagen, die hopeloos vastgelopen scheen, weer op gang te krijgen. Er moest nu eenmaal geregeerd worden en een langere duur van de crisis (welhaast vier maanden waren nutteloos voorbijgegaan) zou fataal kunnen worden. Reeds bij de eerstvolgende Kamerverkiezing, die in 1929 zou plaatsvinden, zou het kabinet onvoorwaardelijk zijn mandaat ter beschikking stellen.

De zaak van het pauselijk gezantschap werd pro forma nog eenmaal aan de orde gesteld en opnieuw afgestemd. Maar ditmaal werd er aan de verwerping geen politieke consequentie verbonden. (Pas tijdens de Tweede Wereldoorlog werd het opnieuw ingesteld en sindsdien vormt het geen geschilpunt meer tussen protestanten en katholieken).

De verkiezingen van 1929 schenen toch weer te wijzen in de richting van een ouderwetse coalitieregering: rechts kreeg een meerderheid (57 zetels, waarvan alleen al de rooms-katholieken er 30 bezetten). Onmiddellijk ging Ruys de Beerenbrouck, aan wie de formatie werd opgedragen, aan het werk. Maar hij kwam niet tot het resultaat dat hem voor ogen stond: een zuiver rechts ministerie met een vast omschreven program. De christelijk-historische Kamerfractie voelde niets voor bindende afspraken betreffende een gemeenschappelijk regeringsprogram ${ }^{50}$. Dit had tot gevolg dat Ruys een kabinet ging vormen, dat wel een rechts karakter droeg, maar dat als extra-parlementair de band met de drie rechtse partijen miste en ook niet door dik en dun door de betrokken fracties zou worden verdedigd tijdens het uitoefenen van zijn functie. Elke fractie zou haar zelfstandigheid behouden tegenover de nieuwe regering.

Dit maakte het contact tussen de drie rechtse partijen zwakker, al bleven de gemeenschappelijke christelijke beginselen de vaste ondergrond. Maar deze beginselen konden niet altijd tot gelding worden gebracht als het bijvoorbeeld ging om zuiver financiële of economische maatregelen. En juist die eisten in de jaren dertig zoveel aandacht op. Het gebeurde dan ook meer dan eens, dat een stemmenmeerderheid te danken was aan het feit dat rechtse Kamerleden instemden met linkse voorstellen en omgekeerd. De scheidingslijn tussen rechtse en linkse groeperingen ging daardoor aan scherpte verliezen. Symbolisch daarvoor was de omstandigheid dat

50. Oud, Om de democratie (1933) IV, 31 vlg. 
de anti-revolutionaire leider Colijn in 1933 overging tot het vormen van een gemengd kabinet, bestaande uit mannen van rechts en van links (onder anderen rooms-katholieken, anti-revolutionairen en vrijzinnig-democraten). Hij achtte nu eenmaal voor een 'crisiskabinet', dat hij in opdracht van de koningin moest formeren, een bredere basis nodig. De socialisten bleken nog niet bruikbaar in dit 'burgerlijk blok', dat samenwerking voorop stelde en tegenstellingen zoveel mogelijk wenste te vermijden met het oog op de bestrijding van de algemene crisissituatie. In de volgende jaren leidden in die benarde tijd verscheidene kabinetscrises tot steeds grotere politieke onzekerheid. Ondanks de leiding van de 'sterke man', waarvoor men Colijn aanzag, ging de vaste lijn ontbreken, omdat geen enkele partij of partijcombinatie pasklare antwoorden had voor de problemen van de praktische politiek. Toch wist Colijn in 1937 weer een rechts kabinet 'op beslist christelijke grondslag' van de grond te krijgen. Maar de samenwerking ging te wensen overlaten toen men tegenover de aanpak van de financiële en economische vraagstukken volstrekt verschillend bleek te denken. En toen aan de vooravond van de Tweede Wereldoorlog het gewenst leek tegenover de internationale dreigingen een einde te maken aan alle politiek geharrewar in de nationale politiek, zocht De Geer zijn toevlucht tot een 'noodkabinet', waarin voor 't eerst in onze parlementaire geschiedenis ook aan socialisten een plaats werd geruimd.

Deze oplossing scheen het definitieve einde van de oude rechtse coalitie. Over bleef slechts de herinnering aan een samenwerkingsverband, dat in het laatste kwart van de negentiende eeuw was ontstaan, in 't begin van de twintigste was gegroeid en effectief had gewerkt en dat in 1925 al gehavend uit de strijd was gekomen.

Toen in 1940 ons land zelf in de greep van de oorlog was gekomen bleek dit desastreus voor de politieke ontwikkeling ten onzent. Het normale parlementaire werk werd volkomen stilgelegd en de wettige regering vertoefde in ballingschap.

Tegen het einde van de oorlog kreeg men nieuwe hoop, ook voor het politieke bestel. In de komende tijd van vrede zouden herstel en opbouw gepaard dienen te gaan met een politieke vernieuwing, waaraan men reeds in de jaren dertig toegekomen scheen.

Doch een volledige 'doorbraak' van het partijwezen, waarnaar velen hadden uitgezien, bleef uit. Wel kwamen er enkele partijen onder nieuwe benamingen en met een opener opzet en een ruimer structuur. De oude SDAP werd Partij van de Arbeid (PVDA); de R.K. Staatspartij werd een Katholieke Volkspartij (KVP). De liberalen kregen een verenigingspunt in de Volkspartij voor Vrijheid en Democratie (WD). Doch de aloude Anti-Revolutionaire Partij (ARP) en de Christelijk Historische Unie (CHU) behielden hun bekende signatuur.

Maar een kenteken van vernieuwing in het partijwezen was toch, dat er kort na het einde van de oorlog voor het eerst een kabinet optrad van een rooms-rode sa- 


\section{C. SUTTORP}

menstelling, waarin KVP en PVDA broederlijk zouden samenwerken. Terecht werd er gesproken van 'het nieuwe bestand'. En al werd in de loop der jaren deze smalle basis verbreed door aansluiting van andere partijen, de vroegere coöperatie van de drie grote christelijke partijen scheen toch voorgoed tot het verleden te behoren.

De politieke constellatie werd er intussen niet duidelijker op en vooral de jaren zestig gaven een verward beeld te zien. Nieuwe partijen en partijtjes werden opgericht, hetgeen de overzichtelijkheid niet ten goede kwam. De formatie van homogene combinaties werd steeds moeilijker. Het benoemen van informateurs, die het ingewikkelde en verantwoordelijke werk van een eigenlijke formateur moesten voorbereiden, belemmerden het zicht op de gang van zaken ${ }^{51}$.

Verkiezingsuitslagen en kabinetscrises boden geen waarborgen voor de samenstelling van een volgend kabinet. Aan de opdrachten tot informatie of tot formatie had men vaak weinig houvast. Primair was: het instellen van een onderzoek naar de mogelijkheden tot oplossing van de crisis. Vervolgens kwam er dan een opdracht tot het formeren van 'een kabinet' (zonder nadere aanduiding) óf van 'een kabinet dat kon rekenen op vruchtbare samenwerking met de volksvertegenwoordiging' of 'op ruime steun in het parlement'. Als uitvloeisel van dergelijke mandaten werden vervolgens allerlei combinaties bedacht en overwogen; waarbij de scheidingslijnen nu eens te scherp uitvielen, dan weer onduidelijk door elkaar liepen. En dit alles moest dan in talloze gesprekken zo mogelijk worden bijgeschaafd, in conclusies samengevat en bij consultaties ter kennis worden gebracht van de koningin. Zo kon een schier eindeloos va-et-vient ontstaan.

Het was geen wonder, dat men in politieke kringen zich voortdurend bleef bezinnen op vernieuwingen in het partijwezen, op aanpassing van de partijprogramma's en op eventuele samenwerking in grotere verbanden.

Het getij scheen gunstig voor het sluiten der gelederen. De deconfessionalisering der christelijke partijen won zienderogen veld. Vele kiezers gingen de eisen der praktijk belangrijker achten dan de 'aloude beginselen'. Bij deze ontwikkeling wisten de linkse groeperingen terrein te winnen. De PVDA zag kans zich op te werken tot de grootste partij. Hechte samenwerking met andere progressieve groepen kon de getalsterkte opvijzelen tot de sterkste minderheid, wellicht tot een parlementaire meerderheid. In verband hiermee gingen ook de drie z.g. confessionele partijen (KVP, ARP, CHU) steeds meer hun heil zoeken in toenadering onderling. De achteruitgang, als gevolg van de 'ontzuiling', drong daar trouwens toe. Zo groeide men, zij het voorzichtig en langzaam, naar meer wederzijdse contacten. Niettemin verliepen de besprekingen over grondslag en organisatievorm in één verband nogal

51. Zie bijvoorbeeld de formatiegeschiedenis van het kabinet-Marijnen in: F. J. F. M. Duynstee, De kabinetsformaties 1946-1965 (Deventer, 1966) 278 vlg. 
moeizaam. Tegelijk echter werd men zich sterker bewust van een geestelijke eenheid, die ondanks alles immers niet verloren geraakt kon zijn.

Maar in de gegeven omstandigheden gaf zelfs de formulering van de gemeenschappelijke grondslag de nodige moeilijkheden. Al werd men het erover eens, dat men het evangelie als richtsnoer voor het politieke handelen zou beschouwen, over de interpretatie en de practische toepassing bleken toch weer genuanceerde opvattingen mogelijk. Ook de vraag, of men bij verkiezingen zou aantreden met één candidatenlijst kon na allerlei discussie worden opgelost. Want bij al deze kwesties sprak natuurlijk ook de achterban der betrokken partijen een woordje mee.

Tenslotte werd de oprichting van het Christen-Democratisch Appel (CDA) een feit. Als organisatie met een christelijke signatuur zou men, opererende vanuit eenzelfde grondslag, streven naar eenheid van politiek beleid. Bij de verkiezingen in 1977 zou dit alvast gesymboliseerd worden in één gemeenschappeüjke candidatenlijst met één lijstaanvoerder.

$\mathrm{Na}$ een wisselvallig bestaan en niet-bestaan gedurende ongeveer een eeuw blijkt de rechtse coalitie der drie christelijke partijen nog steeds, zij het omstreden, een realiteit. Meer dan eens was ze in het verleden een medebepalende factor van belang in het Nederlandse politieke leven. Of in de geladen partijenstructuur van heden de nieuwe formatie levensvatbaarheid zal hebben en eventueel zal behouden - hetzij als regeringscombinatie, hetzij als oppositionele organisatie - zal de toekomst moeten uitwijzen. 


\title{
De Nederlandse regering in Londen en de 'Vrije Fransen'
}

\author{
A. F. MANNING
}

De Nederlandse regering in Londen heeft in de zomer van 1940 serieus rekening gehouden met de vredeskansen die er volgens velen waren. Beraad in eigen kring bewijst dat. Het blijkt duidelijk uit de Nederlands-Engelse betrekkingen en uit de relatie tot het bewind van Pétain te Vichy. Ook de Nederlandse houding ten opzichte van Italië is daarvan een voorbeeld. Pas in het najaar van 1940 zocht Nederland de status van volwaardig en zelfstandig bondgenoot van de Engelsen. Die lichtten de Nederlanders overigens naar hun zin te weinig in en betrokken hen niet in de oorlogvoering, preciezer gezegd in het militaire beraad en politieke beleid. Sinds oktober wilde de regering Gerbrandy daar wel in gekend worden en zij wees de Engelsen op het economisch potentieel van Nederlands-Indië en op de belangrijke handels- en oorlogsvloot die aan de Duitsers ontkomen was. Nederland, zo luidde de redenering, diende als een bondgenoot van betekenis en als een middle power te worden beschouwd, te onderscheiden van allerlei andere regeringen in Londense ballingschap. In het voorjaar van 1942, na de verovering van Indië door Japan, verzwakte de Nederlandse positie maar verdween de pretentie niet. Men kan niet zeggen dat de Engelsen en later de Amerikanen deze zienswijze van de Nederlandse regering wilden volgen. $\mathrm{Zij}$ schatten de gevechtskracht van de Nederlanders in Indië niet hoog en zij konden of wilden zich niet hecht aan Nederland binden voor de verdediging van de koloniën. In het algemeen werd de Nederlandse buitenlandse politiek tijdens de Tweede Wereldoorlog gekenmerkt door zorgvuldig koopmanschap en diplomatieke voorzichtigheid. Ze was afgestemd op de Engelse politiek en hield in tweede instantie sterk rekening met de Amerikaanse gevoelens.

De Fransen waren op 10 mei 1940 bondgenoot geworden in de strijd tegen Duitsland. Enige militaire samenwerking kwam tot stand en Franse troepen hebben in die meidagen in Zuidnederland gevochten. Nederland onderhield na de wapenstilstand van Frankrijk met Duitsland tot begin september 1940 vanuit Londen betrekkingen met de regering-Pétain. Die relaties zijn na Duitse pressie op Vichy verbroken. Daarna ontwikkelde zich langzamerhand het contact met de groep rond generaal De Gaulle. Aanvankelijk was het niet meer dan een comité waartegenover 